\title{
Geologic controls on gas hydrate occurrence in the Mount Elbert prospect, Alaska North Slope
}

\author{
Ray Boswell ${ }^{\mathrm{a}, *}$, Kelly Rose ${ }^{\mathrm{a}}$, Timothy S. Collett ${ }^{\mathrm{b}}$, Myung Lee ${ }^{\mathrm{b}}$, William Winters ${ }^{\mathrm{c}}$, \\ Kristen A. Lewis ${ }^{\text {b }}$, Warren Agena ${ }^{b}$ \\ a National Energy Technology Laboratory, Morgantown, WV 26507, USA \\ ${ }^{\mathrm{b}}$ U.S. Geological Survey, Denver, CO, USA \\ ${ }^{\mathrm{c}}$ U.S. Geological Survey, Woods Hole, MA, USA
}

\section{A R T I C L E I N F O}

\section{Article history:}

Received 16 July 2009

Received in revised form

20 November 2009

Accepted 6 December 2009

Available online 21 December 2009

\section{Keywords:}

Mount Elbert well

Gas hydrate

Alaska North Slope

Milne Point

Sagavanirktok formation

\begin{abstract}
A B S T R A C T
Data acquired at the BPXA-DOE-USGS Mount Elbert Gas Hydrate Stratigraphic Test Well, drilled in the Milne Point area of the Alaska North Slope in February, 2007, indicates two zones of high gas hydrate saturation within the Eocene Sagavanirktok Formation. Gas hydrate is observed in two separate sand reservoirs (the $D$ and $C$ units), in the stratigraphically highest portions of those sands, and is not detected in non-sand lithologies. In the younger D unit, gas hydrate appears to fill much of the available reservoir space at the top of the unit. The degree of vertical fill with the D unit is closely related to the unit reservoir quality. A thick, low-permeability clay-dominated unit serves as an upper seal, whereas a subtle transition to more clay-rich, and interbedded sand, silt, and clay units is associated with the base of gas hydrate occurrence. In the underlying $C$ unit, the reservoir is similarly capped by a clay-dominated section, with gas hydrate filling the relatively lower-quality sands at the top of the unit leaving an underlying thick section of high-reservoir quality sands devoid of gas hydrate. Evaluation of well log, core, and seismic data indicate that the gas hydrate occurs within complex combination stratigraphic/ structural traps. Structural trapping is provided by a four-way fold closure augmented by a large western bounding fault. Lithologic variation is also a likely strong control on lateral extent of the reservoirs, particularly in the D unit accumulation, where gas hydrate appears to extend beyond the limits of the structural closure. Porous and permeable zones within the $C$ unit sand are only partially charged due most likely to limited structural trapping in the reservoir lithofacies during the period of primary charging. The occurrence of the gas hydrate within the sands in the upper portions of both the C and D units and along the crest of the fold is consistent with an interpretation that these deposits are converted free gas accumulations formed prior to the imposition of gas hydrate stability conditions.
\end{abstract}

Published by Elsevier Ltd.

\section{Introduction}

Gas hydrate is a common term used to describe clathrate compounds consisting of a solid lattice of water molecules that efficiently encapsulate molecules of various natural gases - most commonly methane. The pressure-temperature conditions that are necessary (but not sufficient) for gas hydrate formation (see Sloan and Koh, 2008) limit the occurrence of gas hydrates to arctic sediments (typically where the geothermal gradient is impacted by permafrost), to sediments within deep lakes and seas, and to shallow oceanic sediments on outer continental shelves and slopes

\footnotetext{
* Corresponding author. U.S. Department of Energy, National Energy Technology Laboratory, Morgantown, WV 26507, USA.

E-mail address: ray.boswell@netl.doe.gov (R. Boswell).
}

where water depths exceed approximately $500 \mathrm{~m}$. Gas hydrate occurs in a variety of forms and a range of geologic settings. In the marine environment, gas hydrate has been documented to occur as disseminated grains filling pores within sands (Riedel et al., 2006; Fujii et al., 2008) and muds (Paull et al., 1996; Yang et al., 2008), as well as complex networks of fracture fills, veins, and nodules primarily in fine-grained sediments (Holland et al., 2008; Collett et al., 2008a; Park, 2008; Hadley et al., 2008). In contrast, permafrost-associated gas hydrates have commonly been reported to be primarily restricted to pore-filling morphologies within sandy sediments (Dallimore and Collett, 2005).

The factors that control the occurrence and distribution of gas hydrate continue to be the subject of much investigation. Primary controls include conditions unique to gas hydrates, including specific ranges of temperature and pressure conditions that vary 
with the geochemistry of both the gas and the water (Sloan and Koh, 2008). In addition, the development of methane hydrate systems require adequate supplies of water, as well as many of the same elements as other hydrocarbon accumulations, including migration pathways for gases in volumes sufficient to exceed the solubility of methane in water at the given pressure and temperature conditions. In addition to adequate sourcing, the ultimate nature and richness of gas hydrate systems appear to be profoundly impacted by the nature of the host sediment, including grain and pore sizes as well as mineralogy. Overall, it appears that deposits of pore-filling hydrate at high saturations (herein considered to be $50 \%$ or more of pore space) require the high intrinsic formation permeability that is only provided in high-porosity sands and sandstones (Dallimore and Collett, 2005; Torres et al., 2008; Uchida et al., 2009).

The formation processes for gas hydrate accumulations in nature are also not well understood. The most commonly invoked mechanisms include 1) formation from dissolved phase methane as it exsolves due to changing solubility as methane-saturated pore waters migrate upward through sediment columns (Hyndman and Davis, 1992); and 2) advection of bubble-phase methane into the gas hydrate stability zone along preferential permeability pathways (faults, inclined permeable strata, and in vent/chimney structures; see Milkov and Sassen, 2002). In addition, conversion of free gas accumulations to gas hydrate by late-stage imposition of gas hydrate stability conditions has been a favored interpretation for gas hydrate accumulations on the Alaska North Slope (Collett, 1993, 2002).

The BPXA-DOE-USGS Mount Elbert Gas Hydrate Stratigraphic Test Well (Mount Elbert Well) was drilled, logged, cored, and pressure tested in February 2007 as part of an ongoing cooperative research and development effort between the Department of Energy's National Energy Technology Laboratory (NETL), BP Exploration (Alaska), Inc., (BPXA), and the U.S. Geological Survey (USGS). This research program aims to better understand the nature and occurrence of gas hydrate on the Alaska North Slope (ANS) and to assess gas hydrate's part in, and impact on, the ANS energy resources (Hunter et al., 2011). The data collection effort at the Mount Elbert site was designed to evaluate and advance geological/ geophysical detection and characterization methodologies, improve confidence in regional assessments of gas hydrate resource volumes, and provide additional reservoir evaluation and numerical simulations to support the selection of a location and operation plans for extended term gas hydrate production testing.

This report attempts to draw additional insights regarding the process of formation and the geologic controls on the areal extent and internal saturation distribution of gas hydrate at the Mount Elbert accumulation using data acquired at the Mount Elbert well in conjunction with features observed in industry seismic data.

\section{Setting}

The Mount Elbert well was drilled vertically from a temporary ice pad within the southeastern portion of the Milne Point Unit (MPU), within the greater ANS infrastructure area (Fig. 1). The ANS has produced large quantities of oil from Permian to Triassic and younger-aged sand and carbonate reservoirs at producing depths greater than $\sim 2000 \mathrm{~m}$ ( $\sim 6500 \mathrm{ft})$ since initial field discovery in 1968. The ANS also has large natural gas resources which are primarily associated with the oil fields. Three major oil fields have been established with the greater Prudhoe Bay region (the Milne Point, Kuparuk River, and Prudhoe Bay oil fields), resulting in the development of extensive infrastructure and geological/geophysical databases. A key aspect of the BPXA-DOE-USGS project is to leverage this data, knowledge, and infrastructure to explore the occurrence and resource potential of gas hydrates.

Within the MPU, hydrocarbons are produced from complex structural/stratigraphic traps within the Lower Cretaceous Kuparuk sand (Carman and Hardwick, 1983; Werner, 1987). The area also contains vast resources in the form of viscous oil within cold and shallow ( $1200 \mathrm{~m}$ : $3940 \mathrm{ft}$ ) Tertiary Schrader Bluff and Ugnu

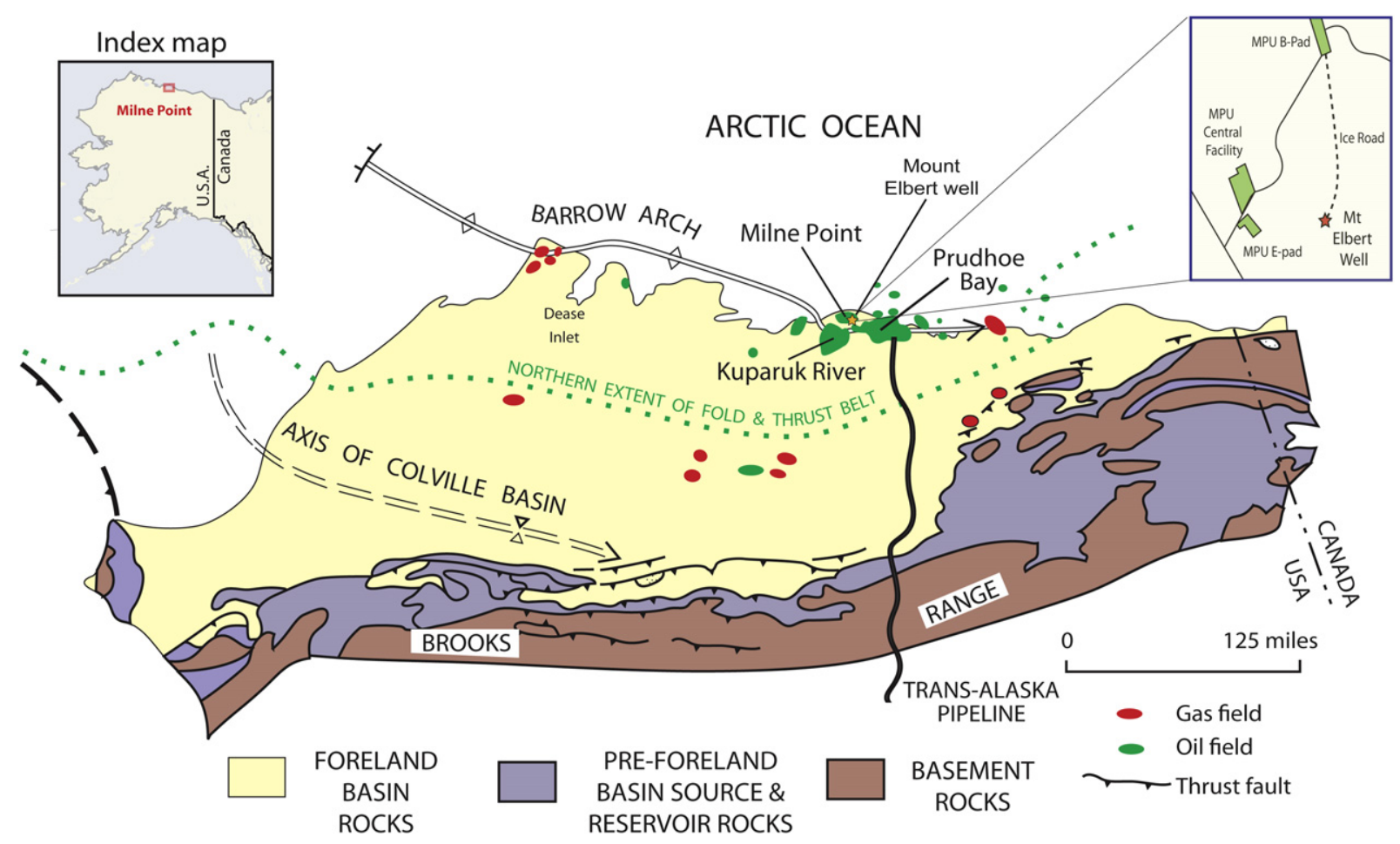

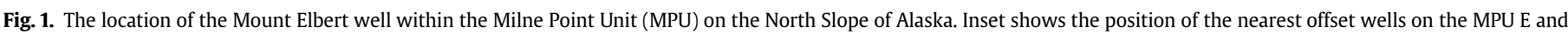
MPU B production pads. 
sands (Werner, 1987; Bidinger and Dillon, 1995). Evaporative fractionation and biodegradation of these oils are considered to be one of the sources for the hydrocarbons trapped within the overlying gas hydrates (Masterson et al., 2001; Lorenson et al., 2011) of the Eileen gas hydrate trend (Collett, 1993; Collett et al., 2011a). Secondary migration of thermogenically sourced gas along major fault systems from the more deeply buried conventional gas and oil fields has also contributed to the gas hydrate accumulations in the Prudhoe Bay, Milne Point, and Kuparuk River units (Collett, 1993; Collett et al., 1990; Valin and Collett, 1992). Overall, gas hydrate in Eileen trend is the shallow extension of the greater Prudhoe Bay region petroleum system.

Gas hydrate occurrence within the area was confirmed as early as 1972 with the drilling and coring of gas hydrate-bearing intervals at the NW Eileen State-2 well (Collett, 1993). Gas hydrate stability conditions on the ANS are extensive: ice-bearing permafrost in eastern MPU extends to a depth of roughly $536.4 \mathrm{~m}(1760 \mathrm{ft})$, and the base of gas hydrate stability is interpreted to extend to a depth of $869.6 \mathrm{~m}$ (2853 ft; see Collett et al., 2011b). The stratigraphic interval of interest for the Mount Elbert drilling includes the informally designated A through E units of Collett (1993), which are commonly found to be gas hydrate-bearing within the Eileen trend of southern MPU, eastern Kuparuk River Unit, and western Prudhoe Bay Unit (Fig. 2).

The $\mathrm{B}, \mathrm{C}$, and $\mathrm{D}$ units cored and logged beneath permafrost at the Mount Elbert location consist predominantly of fine-grained to very fine-grained sands and coarse silts with minor amounts of thinly interbedded coarse sands, conglomerates, and shales deposited in a range of nearshore marine and non-marine environments (see Collett, 1993; Rose et al., 2011). These sand units occur within the largely non-marine Tertiary Sagavanirktok Formation (Molenaar et al., 1987; Rose et al., 2011), but are clearly differentiated within this unit as they show enhanced lateral continuity throughout the MPU and beyond as compared to both overlying and underlying Sagavanirktok units. These sand units are also distinctive in that they commonly display gradational bases and relatively sharp upper contacts with a progressive upward decrease in shale content (as inferred from "cleaning-upwards" profiles on gamma-ray logs; Fig. 3) - features that are typical of progradational marine and shoreline units. Furthermore, the B, C, and D units are generally overlain by relatively thick and laterally-continuous mud-rich sections. Therefore, this section is believed to represent the interval of maximum influence of marine and transitional environments within the thicker, generally non-marine and highly lenticular sand units of the Sagavanirktok Formation and are likely age-equivalent to the more distal early Eocene marine shales and minor sands of the Mikkelsen Tongue of the Canning Formation further to the east (Molenaar et al., 1987; Bird, 1998). Rose et al. (2011) and Collett et al. (2011a,b) provide more information on the regional and local geology of sediments evaluated at the Mount Elbert well.

The site for the Mount Elbert well was selected to test one of 14 gas hydrate-saturated sand prospects in the MPU that had been interpreted utilizing industry 3-D seismic data (Inks et al., 2009). Among the MPU prospects, the Mount Elbert accumulation was

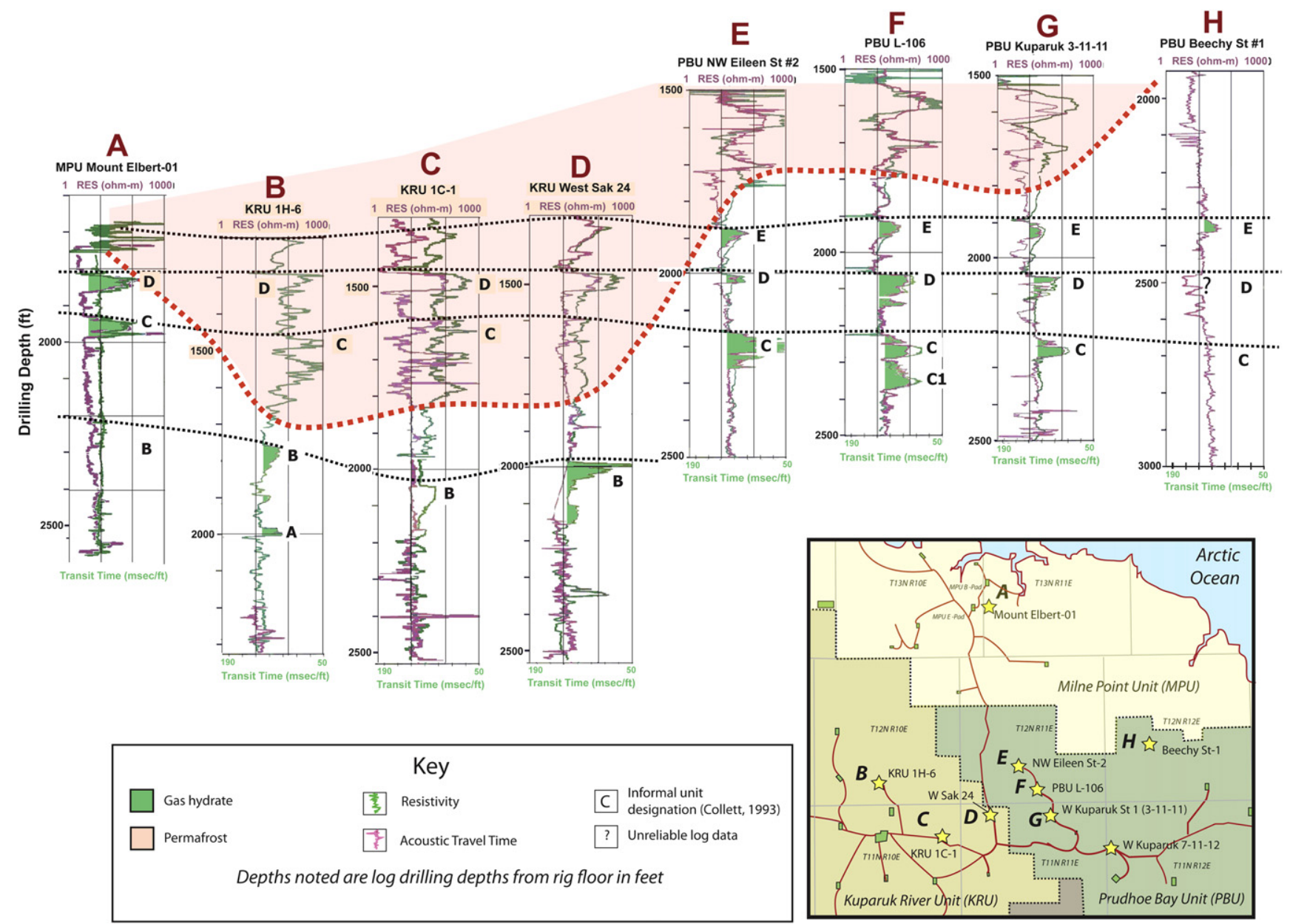

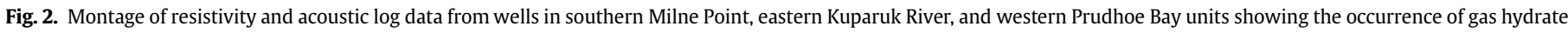
(green) within the interval below the base of permafrost (red dashed line). Black letters indicate informal sand-unit designations after Collett (1993). 


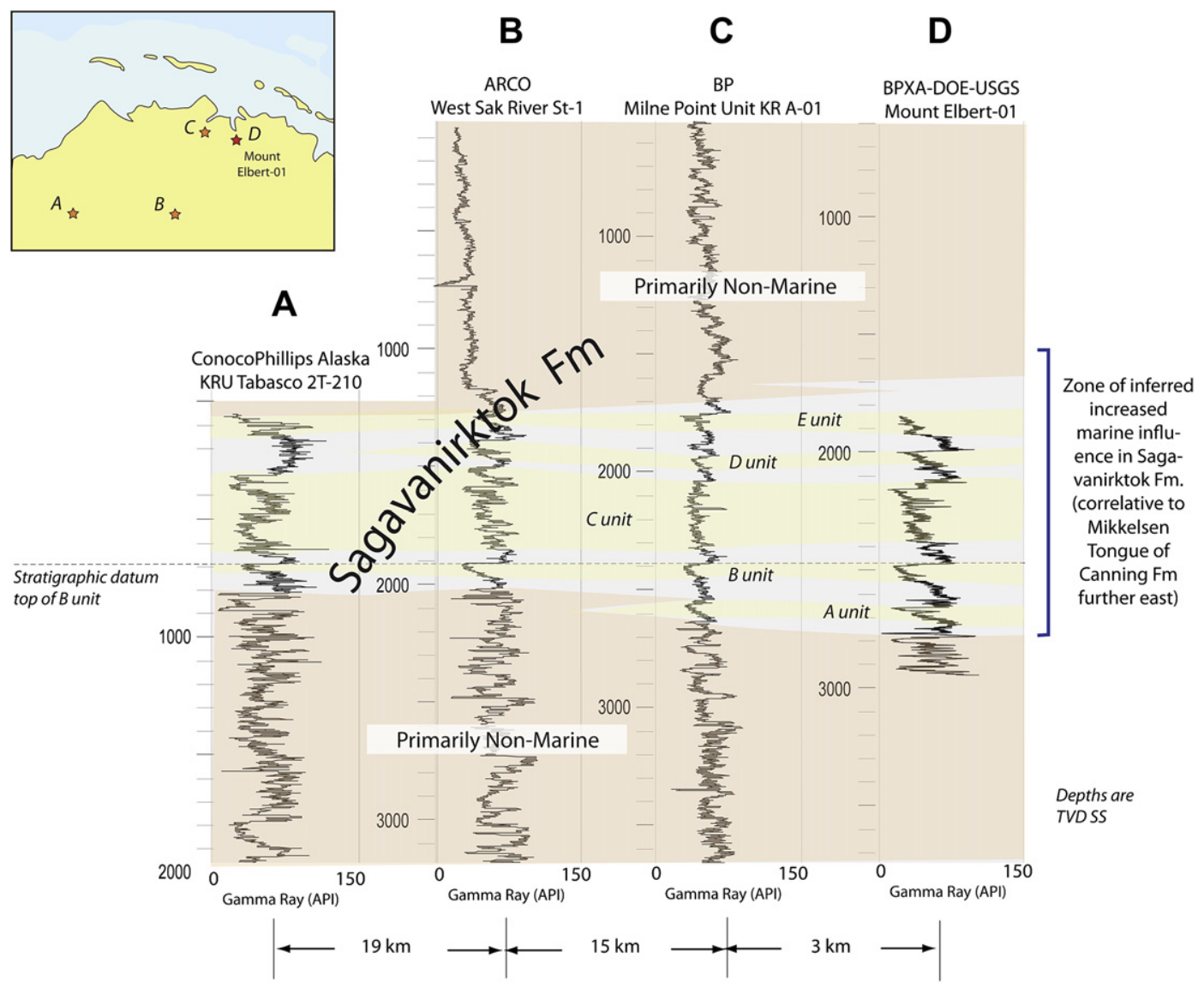

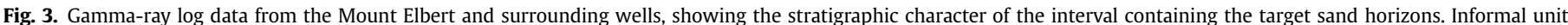
designations (D, C, B) after Collett (1993).

favored as it afforded two vertically stacked targets with strong seismic amplitudes of positive polarity (consistent with anomalously stiff sediments suggestive of gas hydrate fill) below the base of icebearing permafrost and that were areally distributed in rough conformance with structure. Seismic ties to nearby well control allowed these anomalies to be correlated to the $C$ and D units. Using the methodology of Lee et al. (2009), gas hydrate-filled sand thickness and gas hydrate saturation $\left(S_{h}\right)$ were predicted prior to the drilling of the Mount Elbert well. As reported by Lee et al. (2011), the $\log$ and core data obtained at the Mount Elbert well closely validates the pre-drill prediction methodology and provides opportunities to further refine those procedures. Sands within the deeper B unit were anticipated to occur well within the gas hydrate stability zone (GHSZ) at the Mount Elbert location, but were predicted in the pre-drill analysis to be fully water-bearing.

Geologic structure within the eastern part of the MPU is dominated by a complex network of normal faults that overprint a general monoclinal structure that dips less than $2^{\circ}$ to the NNE (Collett, 1993; Molenaar et al., 1987; Bird, 1998; Inks et al., 2009). A structure map constructed for the top of the D unit (Fig. 4) for the immediate area around the Mount Elbert well shows several normal faults of varying throw that generally trend from SW to NE. This map also indicates the potential occurrence of several smaller faults and fault splays with general SE to NW trend and minimal or unclear offset. In addition to the faults, an array of folds with $\mathrm{N}-\mathrm{S}$ and $\mathrm{E}-\mathrm{W}$ trending axes interact with each other and the faults to produce a number of small structures that locally reverse the overall NNE dip of the sediments and create a number of low-relief fold closures. Fig. 4 indicates that the Mount Elbert well was drilled vertically near the crest of one of these anticlinal structures (herein called the "Mount Elbert structure"), which at the top of the D unit exhibits perhaps no more than $5 \mathrm{~m}$ (16 ft) of four-way structural closure. The Mount Elbert structure occurs on the upthrown side of a down-to-the-west normal fault (herein called the "Mount Elbert fault") that shows approximately $20 \mathrm{~m}(65 \mathrm{ft})$ of displacement in the vicinity of the well. The Mount Elbert fault separates the Mount Elbert well from the nearest well control, which includes wells drilled from the MPU E-pad, roughly $915 \mathrm{~m}$ (3000 ft) west of the Mount Elbert well, and the MPU B-pad, approximately $1900 \mathrm{~m}$ $(6230 \mathrm{ft}$ ) to the north (see Fig. 8 of Hunter et al., 2011).

\section{Gas hydrate occurrence at the Mount Elbert well}

Observations derived from the Mount Elbert log and core data confirm the presence of gas hydrate-bearing sands in both the $C$ and $\mathrm{D}$ units. Estimation of the abundance of gas hydrate is based on interpretation of well logs (Collett et al., 2011a,b; Lee and Collett, 2011; Sun et al., 2011), as well as formation water geochemical data obtained from the Mount Elbert cores (Torres et al., 2011). These datasets enable various indirect and independent measurements of gas hydrate saturation $\left(S_{h}\right)$; however, the exact nature and volume of in situ gas hydrate remains imprecisely known, particularly when (and if) gas hydrate saturations are less than roughly 20\%. At values greater than approximately $20 \%$, both the log and core-derived $S_{h}$ estimates compare closely. Using the more complete log-data set for reference, there is a cumulative thickness of $26.7 \mathrm{~m}(87.6 \mathrm{ft})$ of gas-hydrate bearing section within the $\mathrm{C}$ and $\mathrm{D}$ sand reservoirs with $S_{h}$ of $20 \%$ or greater (Fig. 5 ). 
Line 300

(Figure 13)

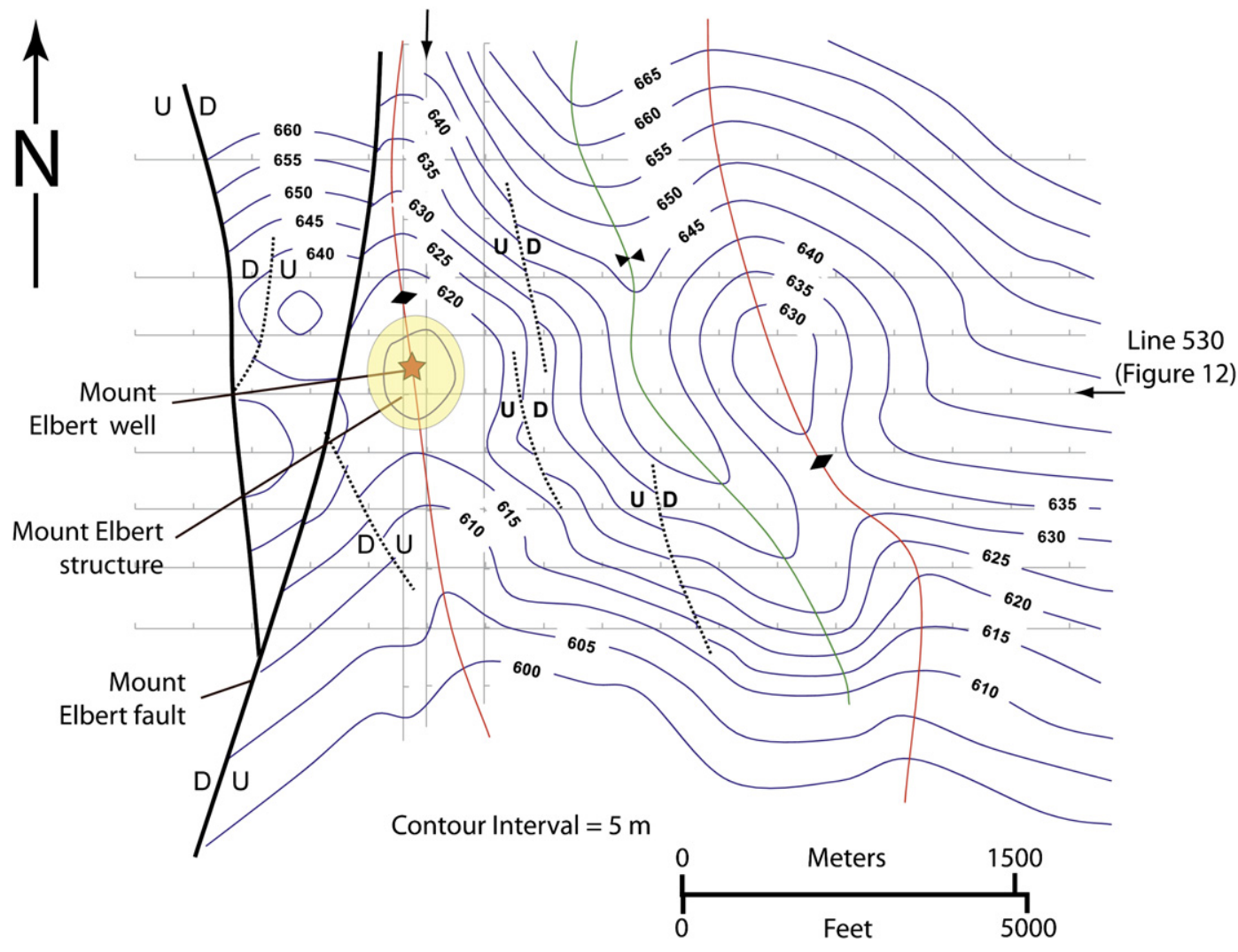

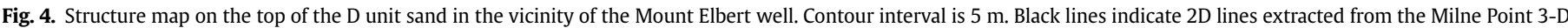

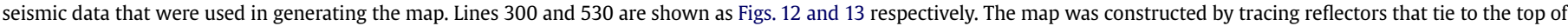

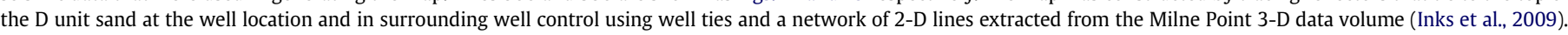

As previously reported for other permafrost-associated gas hydrate regions (Collett, 1993; Dallimore and Collett, 2005), unambiguously-detectable gas hydrate in the Mount Elbert accumulation is restricted to sand-dominated lithologies. Within the D unit, gas hydrate in excess of $20 \% S_{h}$ (from log-based interpretations) occurs from $614.4 \mathrm{~m}$ to $627.9 \mathrm{~m}(2016.2 \mathrm{ft}-2060 \mathrm{ft})$. Within the main body of the D unit accumulation (from 617 to $626.8 \mathrm{~m}$ : $2024-2056 \mathrm{ft}), S_{h}$ averages $65 \%$. In the $C$ unit, significant $\left(S_{h}>20 \%\right)$ gas hydrate occurs in the interval between 649.8 and $666.3 \mathrm{~m}$ $(2132.2 \mathrm{ft}-2169.5 \mathrm{ft})$ with $S_{h}$ again averaging $65 \%$ within the main body of the accumulation (from $651.2 \mathrm{~m}$ to $660.5 \mathrm{~m}$ : $2136 \mathrm{ft}-$ $2186 \mathrm{ft}$ ). In both zones, maximum $S_{h}$ as determined from both core and log data at the Mount Elbert reaches roughly 75\% (Lee and Collett, 2011; Torres et al., 2011).

The occurrence of gas hydrate beyond the main zones of consistent high saturation is not clear. Log data shows no compelling or consistent evidence of gas hydrate outside the two primary zones (Lee and Collett, 2011). Pore water chlorinity data (Torres et al., 2011) agrees well with the log data in delineating the tops and bases of the highly saturated gas hydrate occurrences in both the $\mathrm{D}$ and $C$ units (Fig. 5). However, the pore-water data also suggest the persistence of low values (10\%-20\%) of $S_{h}$ within the lower portions of both the $\mathrm{D}$ and $\mathrm{C}$ units. In the $\mathrm{D}$ sand, this zone of low $S_{h}$ extends to a depth of $\sim 640 \mathrm{~m}(\sim 2100 \mathrm{ft})$ : in the $C$ sand, low $S_{h}$ values from pore water analyses appear to extend to a depth of $\sim 686 \mathrm{~m}$ ( $\sim 2250 \mathrm{ft}$ ). In addition, analysis of EPT log data (a high-frequency, high-vertical resolution resistivity log; see Sun et al., 2011) indicates the presence of gas hydrate at high $S_{h}$ within several sand units that may be too thin to be properly resolved in acoustic and resistivity log datasets within the lowermost portion of the $C$ unit. Core description indicates that thin sand beds do occur throughout the lower portions of both units, however, given the uncertainty in log-to-core depth correlation, direct comparison of such thin units between the core and EPT data are not reliable. At this time, the implications of these differences in interpretation of $S_{h}$ are not clear, and may represent either true differences in the resolution capability of the different methods (both in terms of the thickness of the units that can be seen and the degree of saturation that can be measured) or unreliable indications of $S_{h}$ by some of the methods. For the purposes of this paper, we have used $S_{h}$ estimates from the Combinable Magnetic Resonance (CMR) log data as the primary dataset for the description of Mount Elbert gas hydrate occurrences.

In the following sections, log data are reviewed and compared to sediment lithologic and physical property data as reported in Rose et al. (2011) and Winters et al. (2011) to describe the nature of, and inferred geologic controls on, gas hydrate occurrence in both the $\mathrm{C}$ and D units within the Mount Elbert accumulation.

\subsection{Gas hydrate within the D unit}

The D unit (equivalent to Lithostratigraphic Subunits II and III (LS II, and LS III) of Rose et al. 2011) occurs between $614.4 \mathrm{~m}$ and $650 \mathrm{~m}$ (2015.2-2132 ft: note: unless otherwise noted, all depths in this report are depths from the rig floor, $16.8 \mathrm{~m}$ (55.18 ft) above mean sea level). Overall reservoir quality (as represented by porosity, shale content 
$\begin{array}{lllllll}\text { A } & \text { B } & \text { C } & \text { D } & \text { E } & \text { F } & \text { G }\end{array}$

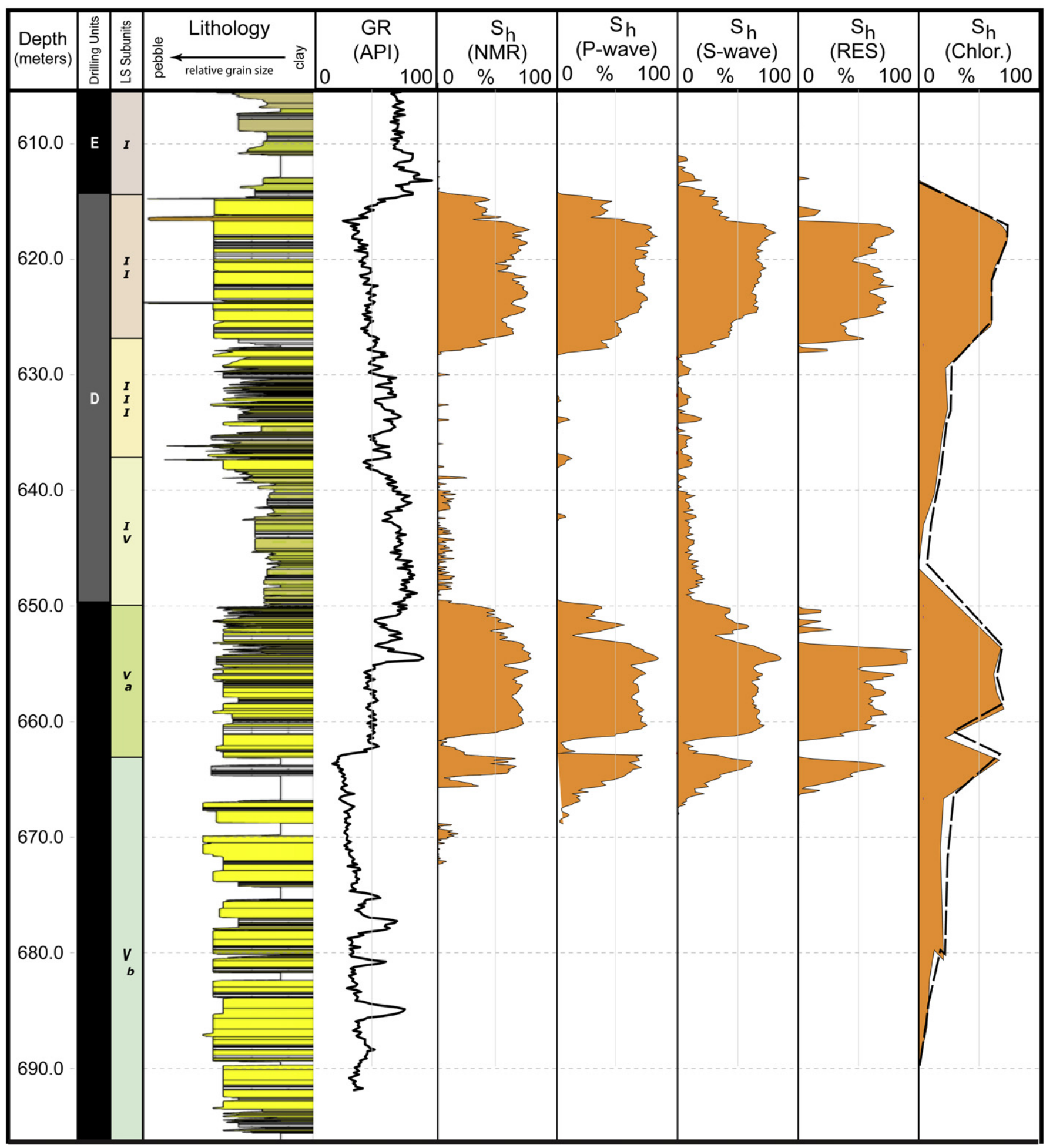

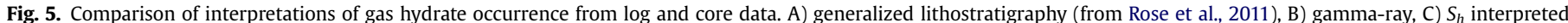

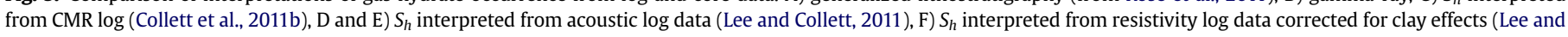
Collett, 2011), G) $S_{h}$ from pore water chlorinity data (Torres et al., 2011). 
as inferred from gamma-ray log data, and permeability) increases upward within the unit, with the best apparent reservoir quality occurring from 617 to $622 \mathrm{~m}$ (2024-2040 ft) where log-derived porosity exceeds $40 \%$ (Fig. 6). Overlying this interval is a $0.5 \mathrm{~m}$ thick interval of relatively low porosity $(\sim 25 \%)$ that corresponds to the lowest radioactivity (lowest inferred shale content) interval seen in the gamma-ray log data for the D unit. Core description (Rose et al., 2011) reveals this zone as a thin and poorly-sorted quartz pebble conglomerate. Above this conglomerate, the upper $2.5 \mathrm{~m}(8 \mathrm{ft})$ of the $\mathrm{D}$ unit exhibits overall upwards reduction in both porosity and sand:shale ratio, as well as reduction in calculated $S_{h}$ (shown in Fig. 6 as bulk-volume gas hydrate). The stratigraphically highest occurrence of gas hydrate (as inferred from the CMR log data) within the D unit occurs at $614.7 \mathrm{~m}$ (2016.2 ft), which corresponds closely to the transition from LS II to the overlying clay-rich LS I. The overlying LS I is more than $12 \mathrm{~m}$ (40 ft) thick and is characterized by relatively low density porosity (27-30\%) and low permeability (0.1-10 md: Winters et al., 2011).

Within the interval of gas hydrate occurrence in the D unit, porosity and $S_{h}$ are consistently high. Notable, however, is the interval of highest porosity (ranging from $40 \%$ to nearly $50 \%$ : zone D-1 of Fig. 6), which shows virtually identical CMR-derived $S_{h}$ as the subjacent interval ( $5 \mathrm{~m}$ of section) where porosity ranges between $32 \%$ and $37 \%$. CMR log data (Fig. 6) indicates that virtually all the additional pore space available within this zone D- 1 is occupied by free water, which locally increases from $10 \%$ to as much as $25 \%$ of pore volume. It is not clear if this zone, which appears to provide underutilized space for additional gas hydrate within the main reservoir interval, reflects some intrinsic upper limit on $S_{h}$, or perhaps is an indication of local limitations in gas charge. As a result of the additional mobile water, CMR-based calculations of in situ permeability $\left(K_{\text {sdr }}\right)$ within zone D-1 exceeds 10 md (Fig. 6), more than an order of magnitude higher than in the bounding units where $K_{\mathrm{sdr}}$ is typically less than $1 \mathrm{md}$. Notably, the presence of a zone of relatively higher mobile water and in situ $K$ may play an important role in accelerating the response of gas hydrate-bearing sand reservoirs to production via depressurization (Anderson et al. 2011). Similar ranges of the free-water saturations and in situ permeabilities were observed in the sand units with high gas hydrate saturations in the Mallik 5L-38 well (Dallimore and Collett, 2005).

Downward from zone D-1, the D unit exhibits a gradual reduction in reservoir quality (reduced porosity and increased shale content). However, despite this apparent gradational decrease in reservoir quality, both the $\log$ and core data indicate a relatively abrupt decrease in $S_{h}$ from $>60 \%$ to $<10 \%$ over a relatively narrow depth interval at the base of the gas hydrate occurrence (zone D-3 of Figs. 5 and 6). Below this level, there is no clear indication of gas hydrate in the resistivity or acoustic log data with the D unit (Fig. 5; see also Lee and Collett, 2011). Notable features that are proximal to the base of gas hydrate in the $\mathrm{D}$ unit include a thin zone of increased formation radioactivity (zone D-2) that counter-intuitively correlates to a slight increase in $S_{h}$; a thin zone of reduced porosity (zone D-4) that coincides closely with the base of gas hydrate at the well, and a zone of high-porosity (zone D-5) that is fully water saturated with $K_{\text {sdr }}$ over 200 md. Below zone D-5, the log data indicates overall reduced and more highly variable reservoir quality than within the hydrate-bearing intervals above, with

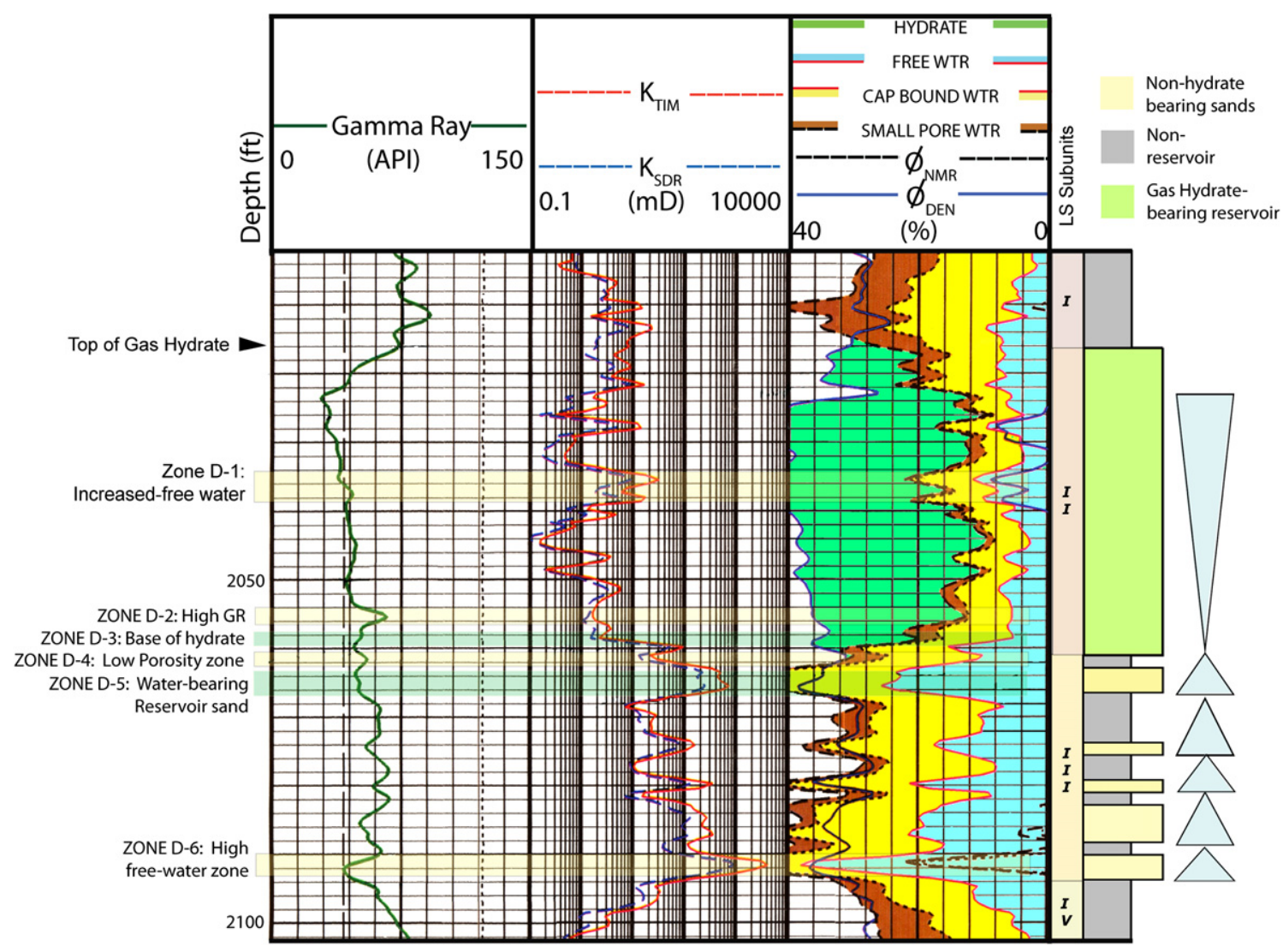

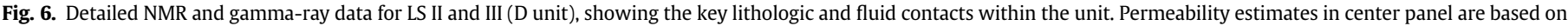

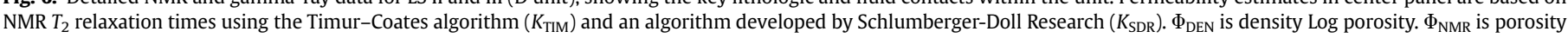

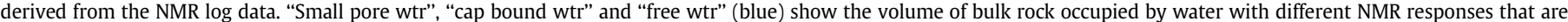

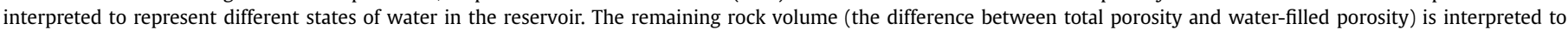

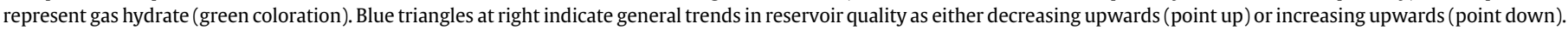


only one additional high-porosity, high $K$ interval (zone D-6) which marks the base of LS II at $637.8 \mathrm{~m}(2092 \mathrm{ft})$. The potential significance of these features in controlling the occurrence of gas hydrate in the D unit is discussed in more detail in a later section.

\subsection{Gas hydrate within the $C$ unit}

From well and core data, the $C$ unit at the Mount Elbert location is comprised of two primary lithologic units (Rose et al., 2011). The lower part (and bulk) of the C unit (LS Vb: from $633.1 \mathrm{~m}$ to $729.0 \mathrm{~m}$; $2176 \mathrm{ft}-2391 \mathrm{ft}$ ) consists of a thick sequence of fine to very-fine sands with rare shale interbeds. As with the D unit, this lower portion of the C-unit exhibits an overall upward increase in reservoir quality as indicated by reduction in gamma-ray inferred shale volume, increasing grain size, increasing porosity, increasing permeability, and decreasing occurrence of significant shale breaks. Reservoir quality within LS $\mathrm{Vb}$ is commonly very high, with porosity $\sim 40 \%$ and CMR-derived and core-derived permeability often exceeding 1 Darcy within many of the sand-rich units. Core description of $\mathrm{LS} \mathrm{Vb}$ reveals a series of individual, coarsening upward sequences dominated by sand beds that tend to be massive (internally structureless) and occasionally amalgamated. The bases of these individual sequences within LS Vb are mostly planar. In contrast, the upper portion of the C unit sand (LS Va: from 650 to $663.1 \mathrm{~m} ; 2133 \mathrm{ft}-2176 \mathrm{ft}$ ) is marked by a succession of thin, finingupwards sequences of very-fine sand, silt, fine silt and clay layers. The sands in LS Va exhibit sub-planar laminations, unlike the primarily massive, structureless sands in LS Vb (Rose et al., 2011). Furthermore, both the core description and the gamma-ray log data indicate a marked shift to greater shale content at the LS Va-Vb contact (Fig. 7). Nonetheless, porosity remains relatively high in the unit ( $\sim 38 \%$ ) with intrinsic permeabilities (defined as permeability of the reservoir with no gas hydrate present) of $100 \mathrm{md}$ or more (Winters et al., 2011).
As in the D unit, gas hydrate in the $C$ unit appears to fill the available reservoir fully to the top of the sand occurrence, extending upwards in the stratigraphic section until gamma-ray readings drop below 75 API units, density log porosity drops below 30\%, and in situ permeability drops below $\sim 10 \mathrm{md}$ (Fig. 7). This horizon (at $650 \mathrm{~m}$; $2132 \mathrm{ft}$ ) corresponds to the top of the $\mathrm{C}$ unit (LS Va) and the base of a $12.5 \mathrm{~m}$ (41 ft) thick, low-permeability, clay-dominated interval (LS IV). Gas hydrate occurs in relatively constant proportions throughout the upper $11 \mathrm{~m}$ of LS Va to a depth of $661.3 \mathrm{~m}(2169 \mathrm{ft})$, where log data indicates a hydrate-free water contact. There is one anomalous zone (zone C-1) in which the gamma-ray log indicates high radioactivity (and high $\mathrm{V}_{\mathrm{sh}}$ ), that corresponds surprisingly to the highest CMR-based $S_{h}$ measurements (77\%) observed in the unit. The base of the unit is water saturated (zone C-2).

On log data, LS Vb is marked by substantial shift to decreased gamma radioactivity (reduced $\mathrm{V}_{\mathrm{sh}}$ ), and slightly higher and more variable porosity. At the top of the unit, corresponding to the lowest gamma-ray reading, is a $1 \mathrm{~m}$-thick interval (zone C-3) of reduced porosity $(<25 \%)$ that corresponds with the "cleanest" (lowest $\mathrm{V}_{\mathrm{sh}}$ ) sands observed in the gamma-ray log data. CMR-log data indicate a high $S_{h}$ in zone $C-3$, indicating perhaps that an increased average grain size and poorer sorting resulted in reduced porosity without substantially impacting intrinsic permeability. Directly below zone C-3 is a high-porosity (38\%-40\% from the density log) sand (zone C4) about $2 \mathrm{~m}$ in thickness. Core data reveal zone C-4 to have the highest average grain size $(210 \mu \mathrm{m})$ and highest intrinsic permeability ( $>7 \mathrm{md}$ ) of any samples taken at the well (Winters et al., 2011). The upper meter of zone C-4 appears to contain gas hydrate at high saturations; while the lower meter appears fully watersaturated, resulting in a second hydrate-free water contact at $664.7 \mathrm{~m}(2181 \mathrm{ft})$. This unit is underlain by a thin zone (zone C-5) of slightly reduced porosity (2184 ft), which is in turn underlain by a thick section of non-gas-hydrate-bearing, high-porosity (40\%), high-permeability ( $K_{\text {sdr }}$ of $\sim 1$ darcy) sands.

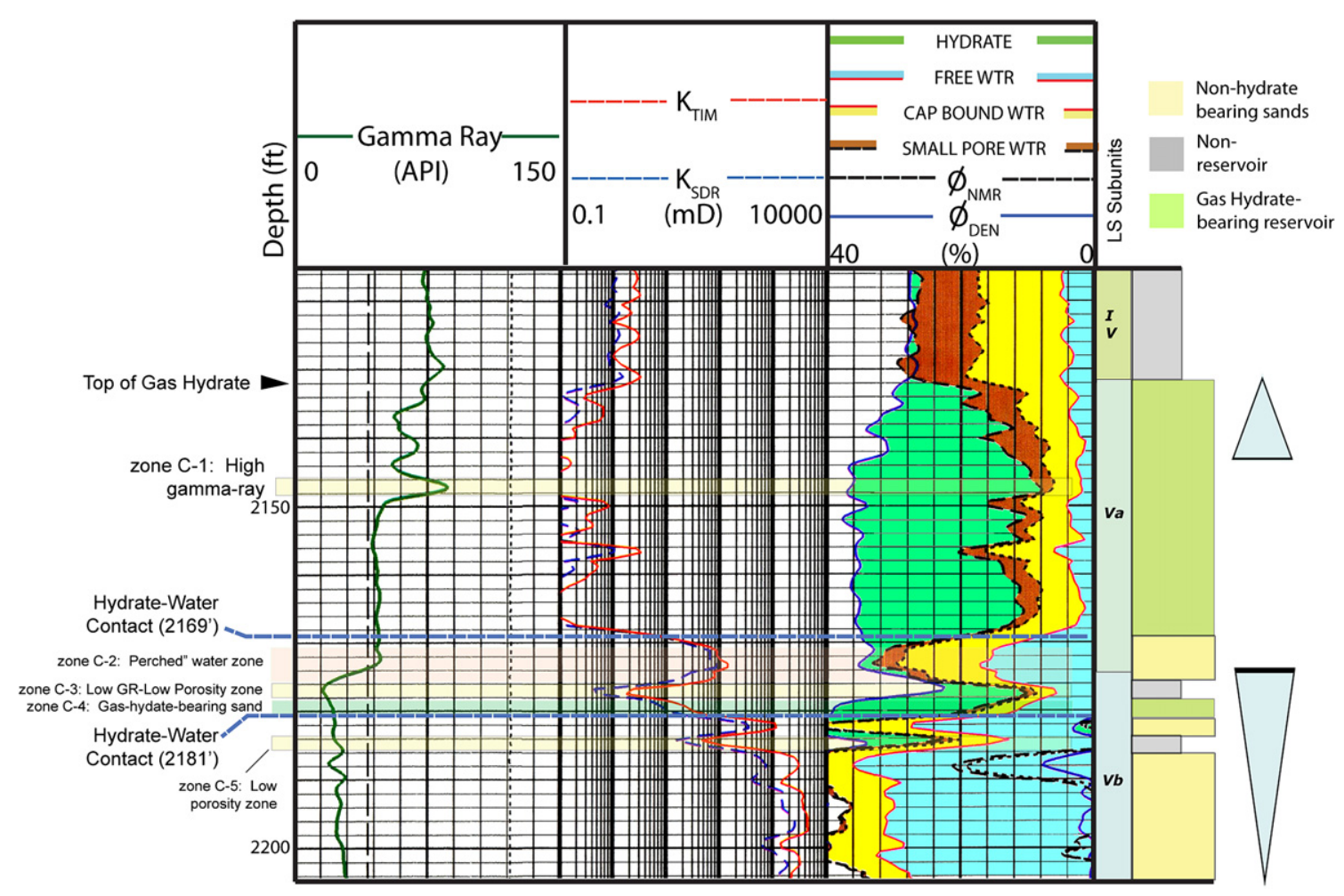

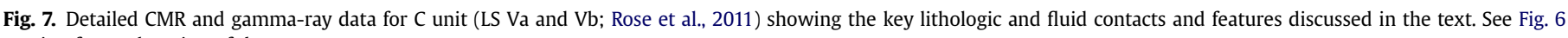
caption for explanation of data. 


\subsection{The B unit at the Mount Elbert well}

The B unit (LS VII: from 756.6 to $759.5 \mathrm{~m}$ in the cored interval; continuing within the lower portion of the hole that was logged but not cored) is a massive, high-porosity (up to $40 \%$ ), high-permeability $\left(K_{\text {sdr }}=3-5\right.$ darcy) sand consisting of two apparent amalgamated coarsening-upwards sequences (Fig. 8). The B Unit contains some of the coarsest-grained and highest permeability sands recovered in the cored interval (Rose et al., 2011; Winters et al., 2011). However, in conformance with pre-drill predictions (Lee et al., 2011), the B unit was found to be fully water-saturated at the Mount Elbert location based on both log and pore water analyses (Lee and Collett, 2011: Torres et al., 2011).

\section{Gas hydrate occurrence within the Mount Elbert structure}

The preceding discussion dealt primarily with the vertical occurrence of gas hydrate-bearing sediments at the Mount Elbert well location. Our understanding of the areal extent of gas hydrate occurrences laterally away from the well location is based primarily on the interpreted distribution of anomalous seismic amplitudes as mapped by Inks et al. (2009) using an industry 3-D seismic survey supplied by BPXA. For both the D and $C$ units, the area of strongest seismic amplitude response occupies a relatively small area in close accordance with the Mount Elbert structure, with large flanking areas of relatively reduced amplitude. The Mount Elbert well was drilled very near the structural crest and penetrated both the $C$ and D units in these areas of highest seismic amplitude response.

To investigate the geologic structural controls on the distribution of gas hydrate at the Mount Elbert site, the regional structure around the well was compared to the distribution of mapped anomalous seismic amplitudes from Inks et al. (2009). Overlaying the areal extent of the seismic anomalies with the local structure maps for both units (Figs. 9 and 10) suggests a complex combination of stratigraphic and structural controls. Structural controls include both the apparent focusing of greatest gas hydrate content over the crest of the Mount Elbert fold as well as lateral trapping by the normal faults, particularly the "Mount Elbert" fault to the northwest. Although this fault may have sealing capabilities of its own, estimates of the fault throw adjacent to the gas hydrate occurrences ( $\sim 20 \mathrm{~m}: \sim 65 \mathrm{ft}$ ) indicate that both the gas hydrate-bearing portions of the $C$ and $D$ units are juxtaposed across the fault plane with lithologies of significantly reduced reservoir quality, aiding in the formation of reservoir traps (Fig. 11). Additional minor splay faults of minimal throw also occur within the structure and may exert some influence on gas hydrate occurrence (primarily as barriers for gas migration along stratigraphic layers within the units); however, the throws on these faults (if any) appear to be minimal and their ability to serve as trapping faults in such thick sands would seem unlikely.

Stratigraphic influence on the occurrence of gas hydrate is very evident in both the $C$ and D units. In the D unit (Fig. 9), there occur two areas where seismic amplitude response suggests gas hydrate as inferred by Inks et al. (2009). The lateral terminations of these anomalies show little relationship to geologic structure. The geometry of the units is illustrated in two example seismic lines from the Milne Point 3-D data set that intersect the Mount Elbert well location (Figs. 12 and 13). When traced to the south (Fig. 12), the gas hydrate occurrence in the D unit tested by the Mount Elbert well is observed to terminate upon the ascending monoclinal slope with no structural control apparent (Fig. 14). To the north, high amplitudes inferred to

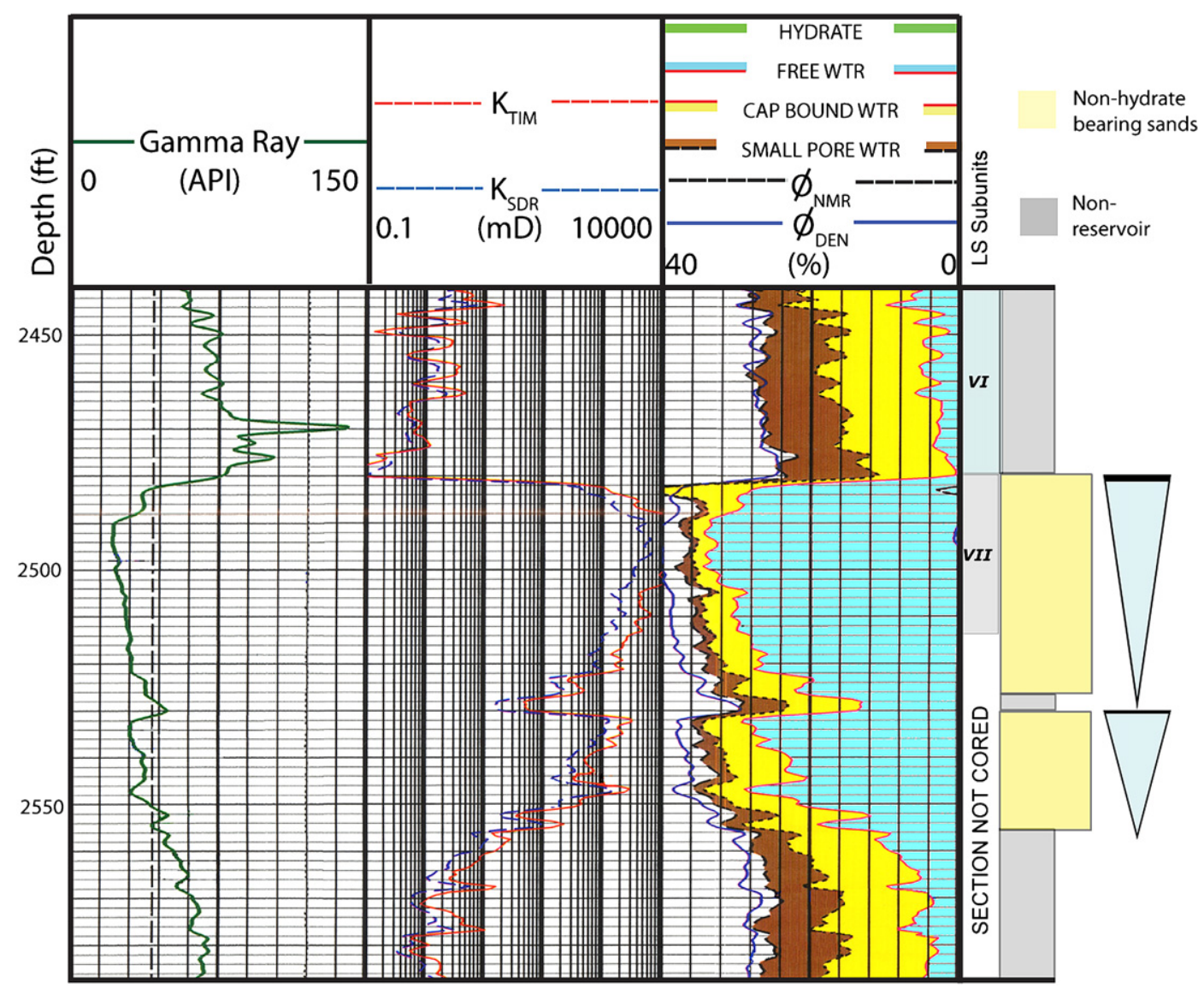

Fig. 8. Detailed CMR and gamma-ray data for the B unit. See Fig. 6 caption for explanation of data. 
Line 300

(Figure 13)

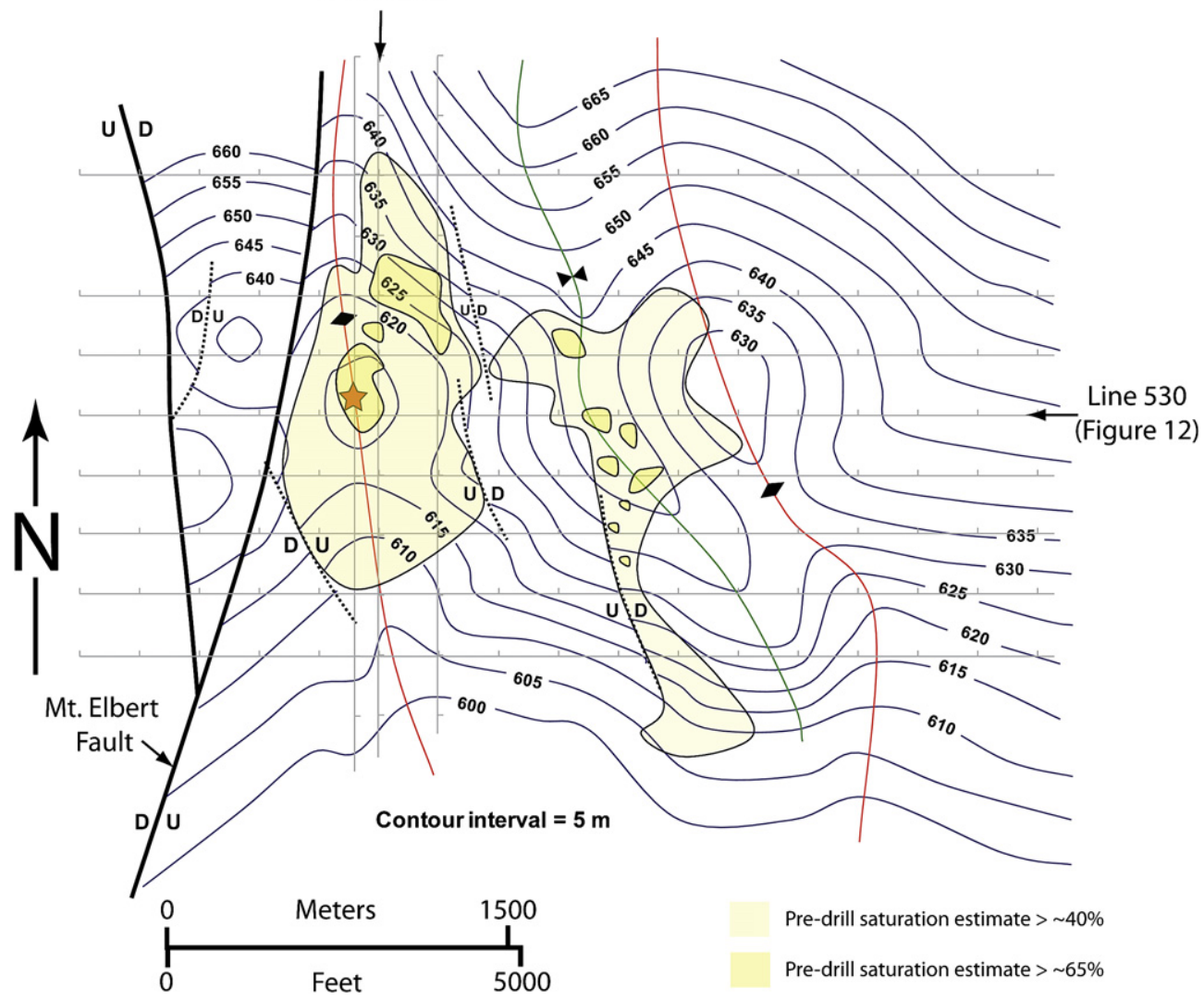

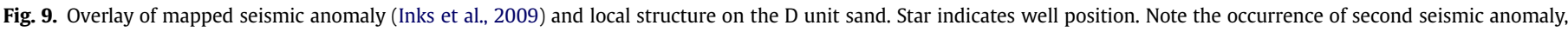

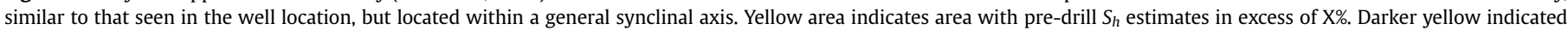
pre-drill $S_{h}$ estimates in excess of X\%.

indicate gas hydrate occurs in units with structural top as deep at $640 \mathrm{~m}(2100 \mathrm{ft})$ - and therefore, presumed structural base of at least

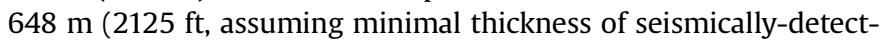
able gas hydrate at $\sim 8 \mathrm{~m}$ in the Milne Point data set per Lee et al., 2009). The second (eastern) accumulation in the $D$ unit is an elongate zone that occurs partially within a structural low (Fig. 9) with possible, but inconclusive, ties to minor faulting. Together, these relationships indicate a high degree of stratigraphic control on the lateral extent of gas hydrate occurrence in the D unit.

At the level of the $C$ unit, the Mount Elbert structural closure is significantly enlarged, and the distribution of the seismic anomalies is more coincident with this structure (Figs. 10 and 11). The discordance between the mapped geologic structure on the top of the $D$ and $C$ units is interpreted to reflect stratigraphic variations on the top of the $C$ unit sand. As traced away from the well location (Figs. 12 and 13), the horizon interpreted to mark the top of the $\mathrm{C}$ unit can be observed to drop within the stratigraphic section, suggesting the lateral disappearance of the upper portions of the C unit (presumably LS Va). This interpreted lateral pinchout (red dashed line on Fig. 10) may be a significant stratigraphic control on the occurrence of gas hydrate in the upper part of the $C$ unit.

\section{Discussion}

\subsection{Lithologic control on gas hydrate occurrence}

Observations at the Mount Elbert well suggest that reservoir lithology exerts a key control on the distribution of gas hydrate.
Most fundamentally, gas hydrate is restricted to sand lithologies within the overall interbedded sand-shale sequence. Within the examined section below permafrost, two main accumulations occur. In both units, gas hydrate occurs within the stratigraphically highest portions of the larger sand sections. This occurs in both the younger D unit, where the highest reservoir quality occurs at the top of the unit, as well as in the older $C$ unit, where the highest reservoir quality occurs largely below the gas hydrate bearing section. In the D unit, gas hydrate fills most of the high-quality reservoir sands in the section. In contrast, gas hydrate only fills a small portion of the total apparent reservoir space in the $\mathrm{C}$ unit, and is largely missing from the most porous and permeable underlying sands (LS Vb).

While the reservoirs within the D and C units are sands, these sands are very-fine grained. Typical grain sizes range from 29 to $229 \mu \mathrm{m}$ with a median and mean grain size of $\sim 84 \mu \mathrm{m}$ (Rose et al., 2011; Winters et al., 2011). Nonetheless, where these units are well sorted, they can be excellent reservoirs, with porosities up to $40 \%$ and permeabilities measured in the darcies. However, due to the very fine dominant grain size, only modest lithologic variations can result in significant changes in reservoir quality. As a result, although there are large volumes of sand present in the section, it appears that only those intervals that are the moderately well-sorted, very fine to fine sands serve as potential reservoir facies. For example, analysis of whole-round cores taken at the Mount Elbert well indicate that reduction in porosity from $37 \%$ to $33 \%$ results in an order of magnitude decrease in intrinsic permeability (Fig. 15: Winters et al., 2011). As porosity drops below 33\% in these sands, coincident to a decrease in the sand-to-silt ratio (Rose et al., 2011), 


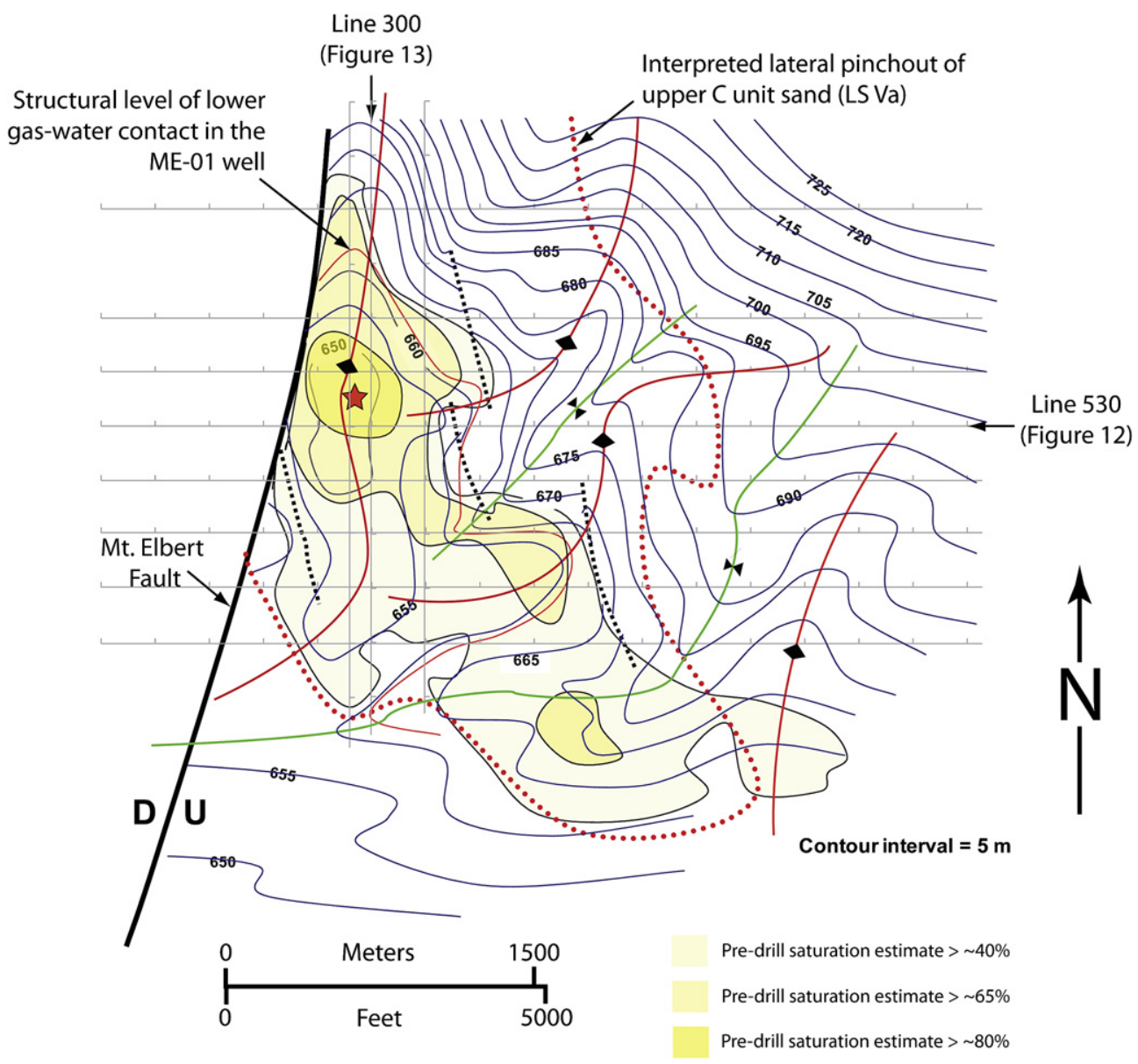

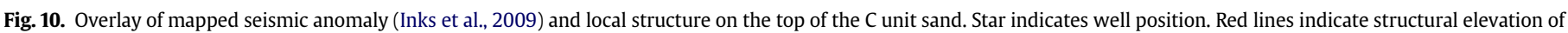
the upper gas-hydrate water contact. Yellow area indicates area with pre-drill $S_{h}$ estimates in excess of X\%. Darker yellow indicated pre-drill $S_{h}$ estimates in excess of X\%.

permeability falls to levels of $10 \mathrm{md}$ and below, creating significant permeability contrasts with only slightly more porous layers. This affect may reflect an increase in pore entry pressures required for gas to migrate through water-wet sediments when pore throats become sufficiently small. The high sensitivity of permeability to modest lithologic variation can be a key contributor to the development of stratigraphic barriers that aid the trapping of gas within this section.

These primary observations at the Mount Elbert location support prior work that has indicated that the occurrence of pore-filling gas hydrate is highly influenced by reservoir properties, with higher $S_{h}$ generally restricted to zones of enhanced permeability (Riedel et al., 2006; Dallimore and Collett, 2005; Uchida et al., 2009; Torres et al., 2008). To investigate if these controls impact the smaller-scale details of $S_{h}$ variation within specific sand reservoirs where gas hydrate occurs, we have plotted $S_{h}$ (as determined at $0.05 \mathrm{~m}$ intervals from the combinable magnetic resonance (CMR) and density porosity logs) against porosity (from the density $\log$ ), core-derived measures of intrinsic (in the absence of gas hydrate) permeability, and sand-shale ratio (as reflected by formation natural radioactivity). These data show a clear but complex link between reservoir quality and $S_{h}$. As shown in Fig. 16a, $S_{h}$ generally increases with decreasing gamma-ray (and therefore decreasing $\mathrm{V}_{\mathrm{sh}}$ ) as expected within the primary gas hydrate bearing units (D unit and upper C unit (LS Va)). The correlation between $S_{h}$ and density porosity is also very well developed (Fig. 16b). However, correlation between core-derived permeability measurements $\left(\mathrm{K}_{\mathrm{mp}}\right.$ : please see Winters et al., 2011, for more discussion on the nature of these measurements) and log-derived $S_{h}$ is less clear (Fig. 16c): nonetheless, these data do show increasing potential for high $S_{h}$ in those units with greater permeability.

The factors that determine the upper limit of gas hydrate occurrence in both the $C$ unit and $D$ unit accumulations at the Mount Elbert site are related to the marked vertical reduction in permeability between the reservoir sands and the overlying clay-dominated, low-permeability sediments. These clay-dominated units have $K_{\text {sdr }}$ typically measured at around $1 \mathrm{md}$ and have clearly served as vertical seals, inhibiting upward gas migration. It is assumed that these units serve as the upper boundaries of the $C$ and $D$ unit accumulation laterally throughout their extent. However, understanding the controls on the base of the gas hydrate occurrence within the sands is more complex, and generally equates to determining the degree of fill in each reservoir. Within both units, the basal contacts are relatively sharp, with reduction in $S_{h}$ from $>60 \%$ to less than $20 \%$ occurring over a depth range of about $2 \mathrm{~m}$ in the $\mathrm{D}$ unit and less than $1 \mathrm{~m}$ in both the upper and lower $C$ units. Two alternative endmember explanations for the sharp nature of these contacts include: 1) the contact is driven by reservoir controls, indicating that this level marks some critical change in reservoir lithology that effectively precluded gas hydrate formation below this depth (i.e. a fully "filled", or lithologically-limited reservoir - at least at the location of the well); or 2) the contact represents a gas hydrate-free water contact within a fully communicating reservoir (i.e., a partially "filled", or charge-limited reservoir) with the level being controlled by some combination of available gas charge and the sealing capability of the 

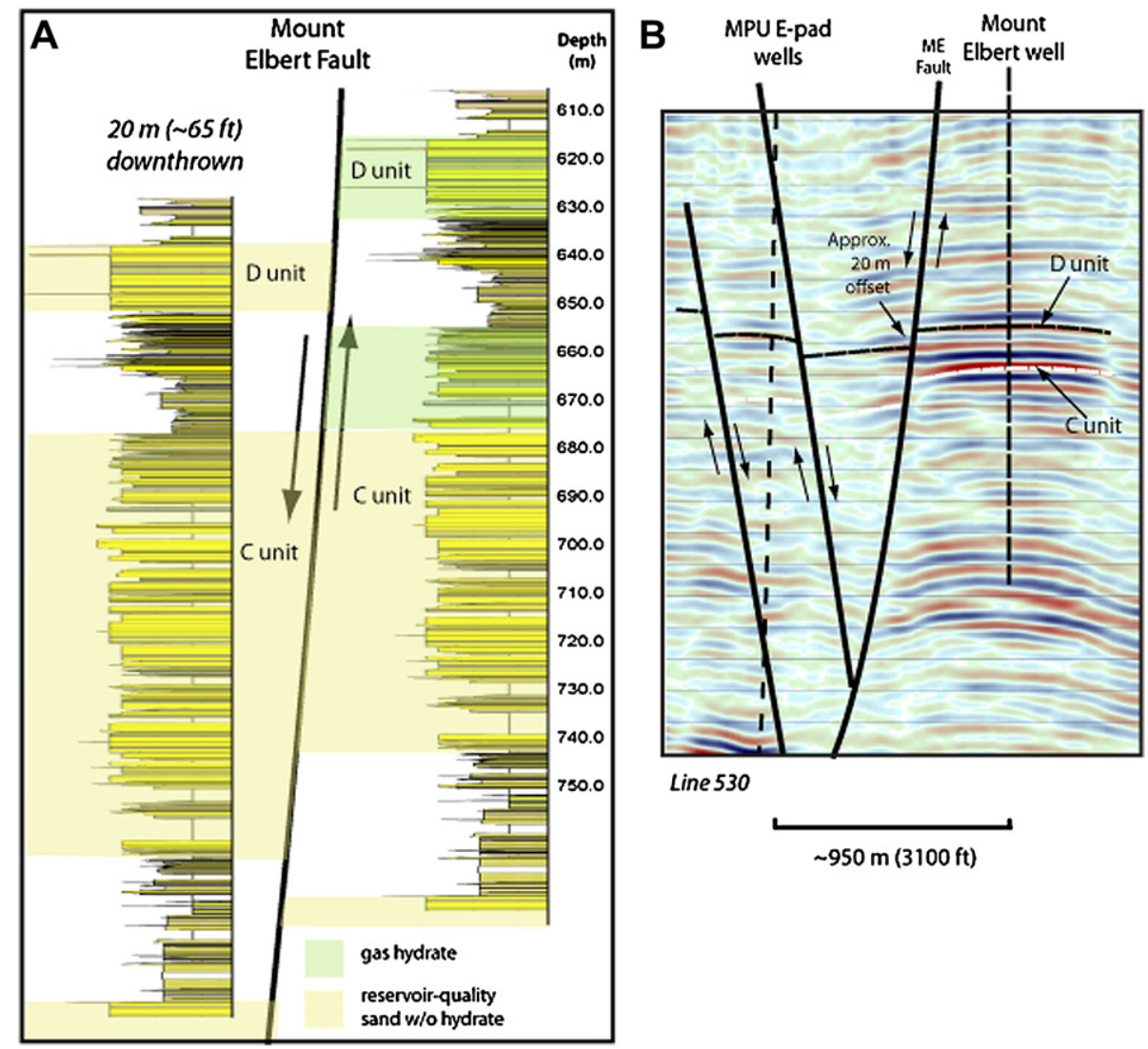

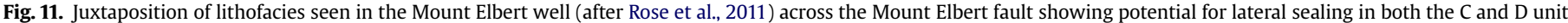
gas hydrate accumulations. A section from seismic line 530 (see Fig. 4 for location) shows the estimated offset on the fault of approximately $20 \mathrm{~m}$ (65 ft).

overlying shale. The issue is further complicated by the need to incorporate processes related to the in situ conversion of an original free gas accumulation into gas hydrate (Behseresht et al., 2009).

Within the $C$ unit, there are two apparent gas hydrate-water contacts as discussed above. Both occur within sand units with no apparent connection to lithologic variation, placing gas-hydrate saturated sand in direct contact with water-bearing sand units. As a result, both contacts within the $C$ unit are attributed to gas hydratewater contacts within fully communicating reservoirs. However, the presence of the two contacts, (leaving a small zone of perched water at the base of zone $\mathrm{C}-3$ ), suggests that the two portions of the $\mathrm{C}$ sand are not effectively in vertical communication, at least at the well location. The water-bearing sand (zone C2: Fig. 7) is associated with a decrease in the sand-to-silt ratio based on grain size analyses and visual core description (Rose et al., 2011) as well as a slight decrease in permeability based on mini-permeameter data (Winters et al., the volume). The gas hydrate-bearing sand directly below zone C2 contains some of the cleanest, sand-rich beds recovered from the entire cored interval, over $90 \%$ sand throughout. These sand zones, C3 and C4, are also some of the coarsest grained with an average grain size of $\sim 220 \mu \mathrm{m}$ placing them in the upper range of the fine sand classification (Rose et al., 2011). The role this relatively subtle and small-scale vertical heterogeneity plays on the occurrence of hydrate saturated sand versus water saturated is not fully understood, but there is a good correlation between the parameters described above. Unfortunately, the lack of core recovered below this interval prevents a similar analysis of the deeper and thinner water saturated interval in the C Unit at $664.7 \mathrm{~m}(2181 \mathrm{ft})$.

Within the D unit, the base of gas hydrate occurs within a zone of overall gradual reduction in reservoir quality (Fig. 6). In support of lithologic control, core data from the D unit indicates that this stratigraphic level (around the base of gas hydrate at $628 \mathrm{~m}$ : $2059 \mathrm{ft}$ ) corresponds to a significant reduction in core-derived estimates of permeability $\left(\mathrm{K}_{\mathrm{mp}}\right.$ : intrinsic permeabilities from minipermeameter tests: see Winters et al., 2011). $K_{\mathrm{mp}}$ above this level routinely measures in the hundreds of md; whereas below, $\mathrm{K}_{\mathrm{mp}}$ varies more erratically, with values $<100$ md being more common (see Winters et al., 2011, Fig. 6). Furthermore, detailed core description and grain size analyses (Rose et al., 2011) indicates that this stratigraphic level also corresponds to fundamental fine-scale lithostratigraphic changes (marking the transition from the underlying LSII to the overlying LS III). This change is primarily marked by a significant increase in the thickness and amalgamation of individual fining-upwards sand beds and general disappearance of clay interbeds and may occur at vertical scales too small to be fully captured in the NMR log data. Perhaps most compellingly, the contact lies less than $0.5 \mathrm{~m}$ above zone D-4, the highest stratigraphic occurrence of density porosity measured less than $32 \%$. Below this zone, there is a significant increase in the percentage of bound water (see Lee et al., 2011), with even the better reservoir sections in the lower portion of the D sand (such as zone D-5), containing more bound water than the upper sands. However, the D-4 and D-5 intervals, including the sands, display lower sand-tosilt ratios than the overlying gas hydrate bearing intervals in the $\mathrm{D}$ Unit (Rose et al., 2011). The increase in fine material and the thinly interbedded nature of this section may be partly responsible for the lack of gas hydrate occurrence in this interval. However, the lateral persistence of such zones (such as zone D-4), and their ability to isolate the gas hydrate-bearing units above from the water-bearing sands below, is not clear. Nonetheless, the sediments within the lower portion of the $\mathrm{D}$ unit would seem to be of sufficient quality to house free gas. Therefore, the apparent lack of gas hydrate is 


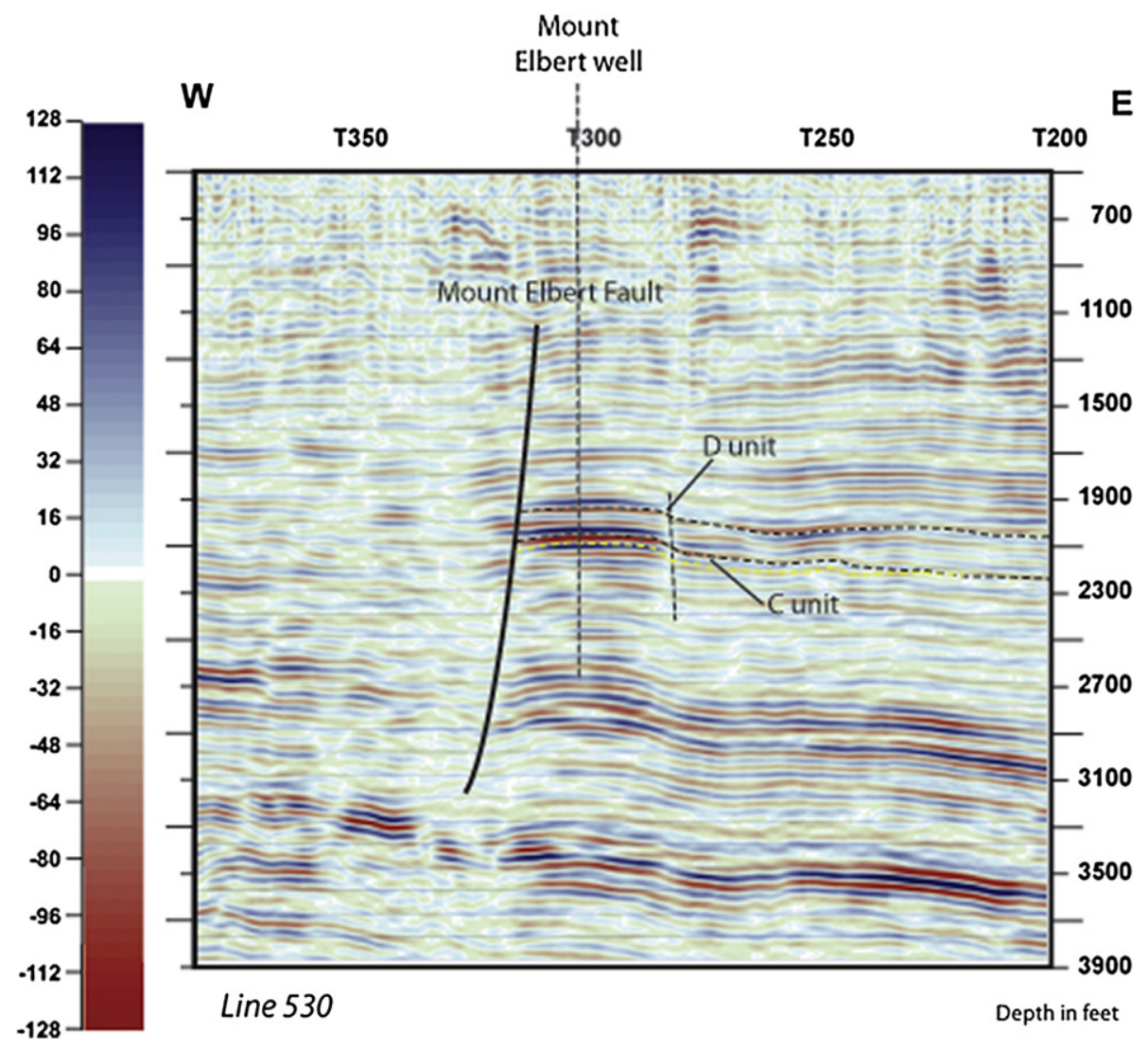

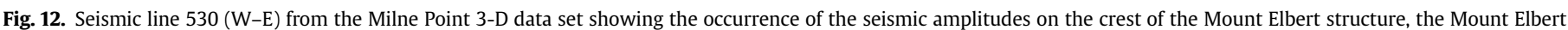
fault, and the potential pinchout of the upper part of the $C$ unit away from the well location.

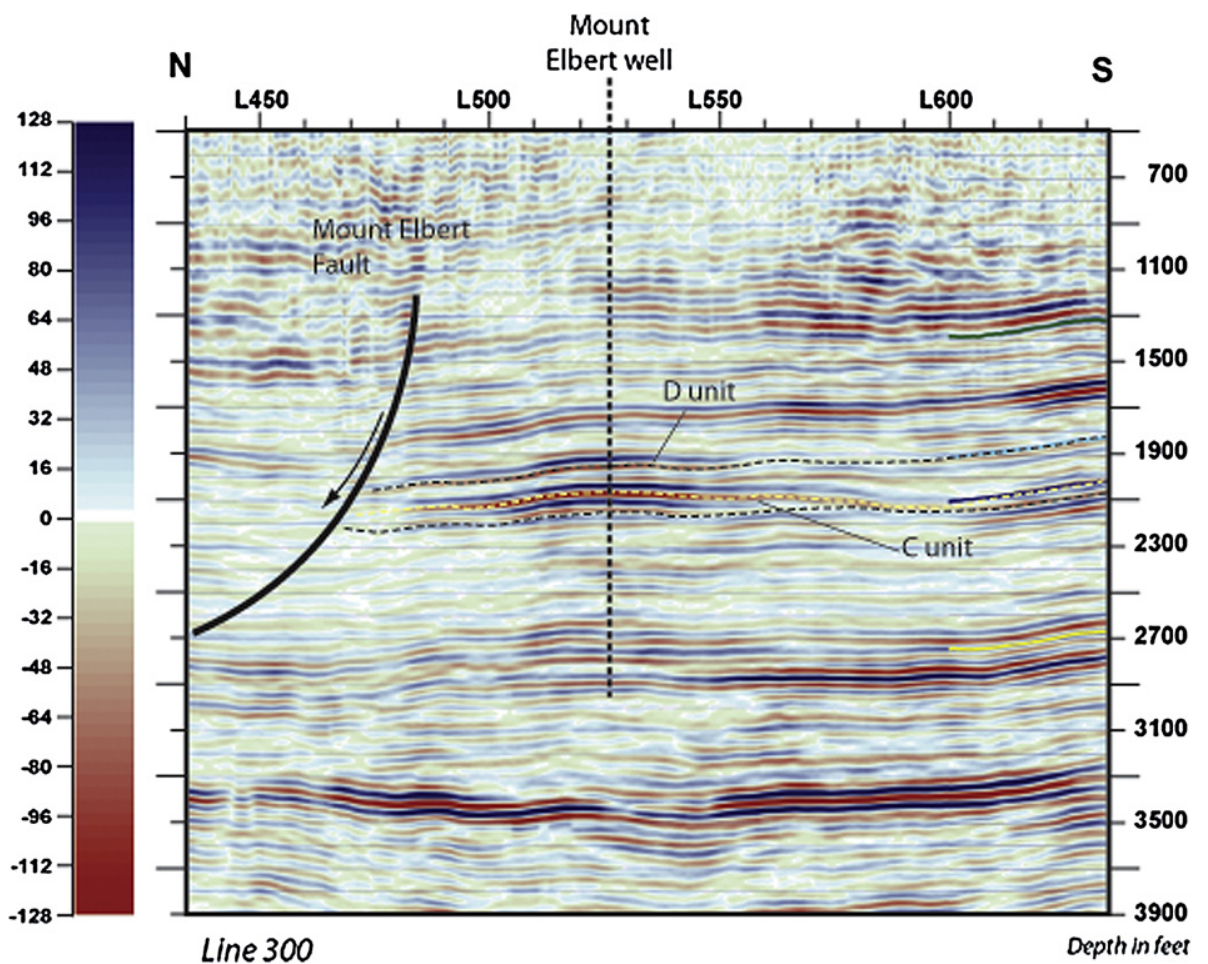

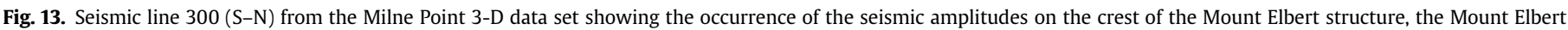
fault, and the potential lateral pinchout of the upper part of the $C$ unit away from the well location. 

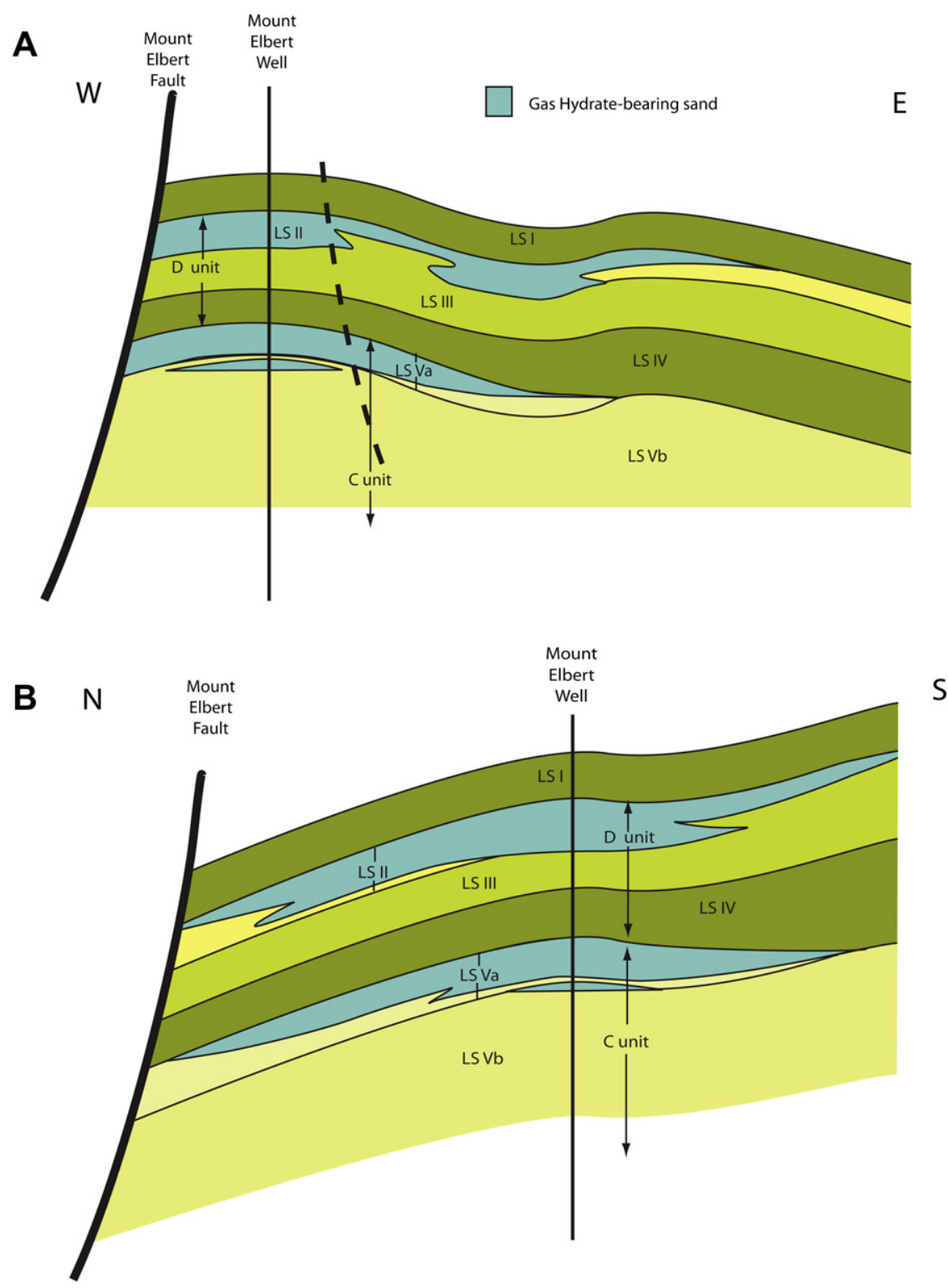

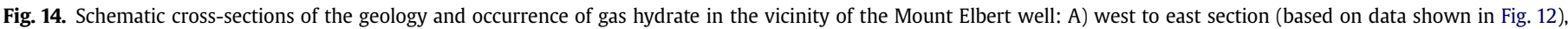
B) south to north section (based on data shown in Fig. 12).

problematic. Possible explanation include simple lack of charge to a level coincident with the lithologic changes described above; a similarly-coincidental limit in the height of the original free gas column that could be maintained by the sealing lithology; removal of free gas and migration upwards during gas hydrate formation to account for overall hydrocarbon volume reduction; or some petrophysical control that selectively limits $S_{h}$ to very low levels during the conversion from free gas to gas hydrate.

It is difficult to conclusively state that the contact at $2059 \mathrm{ft}$ within the D unit does not represent a gas hydrate-free water contact within a fully communicating reservoir. In this case, the volume of unfilled reservoir (within the vertical section observed in the Mount Elbert core and log datasets) would likely be limited to $2.5 \mathrm{~m}(8 \mathrm{ft}$ ) thick (the zone D-5 sand). If this sand does reflect a water-bearing basal zone within the $\mathrm{D}$ unit reservoir, it may reflect either a volume reduction related to the conversion to gas hydrate of a previously gas-filled reservoir (leaving some reservoir area vacated), or insufficient gas sourcing, or a combination of the two.

\subsection{Mode of formation}

A key issue posed by the gas hydrate accumulations at Mount Elbert (and throughout the Arctic) is: how did they form? As mentioned above, previous workers have suggested that these reservoirs may represent free gas accumulations that were converted to gas hydrate when gas hydrate stability conditions were imposed across the ANS roughly 1.8 Ma (Collett, 1993, 2002). The physical processes by which this conversion might happen are not well understood. Nor is it clear that when it happens, if the increased methane density of gas hydrate as compared to free gas would be expressed by a volume reduction (and upward shift in hydrocarbonwater contact) or by general saturation reduction, or by some combination of the two. Nonetheless, there are several aspects of Arctic gas hydrate accumulations that support the interpretation of conversion of free-gas to gas-hydrate accumulation. First, gas hydrates at MPU (where the details of gas hydrate occurrence within the broader gas hydrate trends has been revealed by the work of Inks et al., 2009) show no preference for accumulation near the base of the 


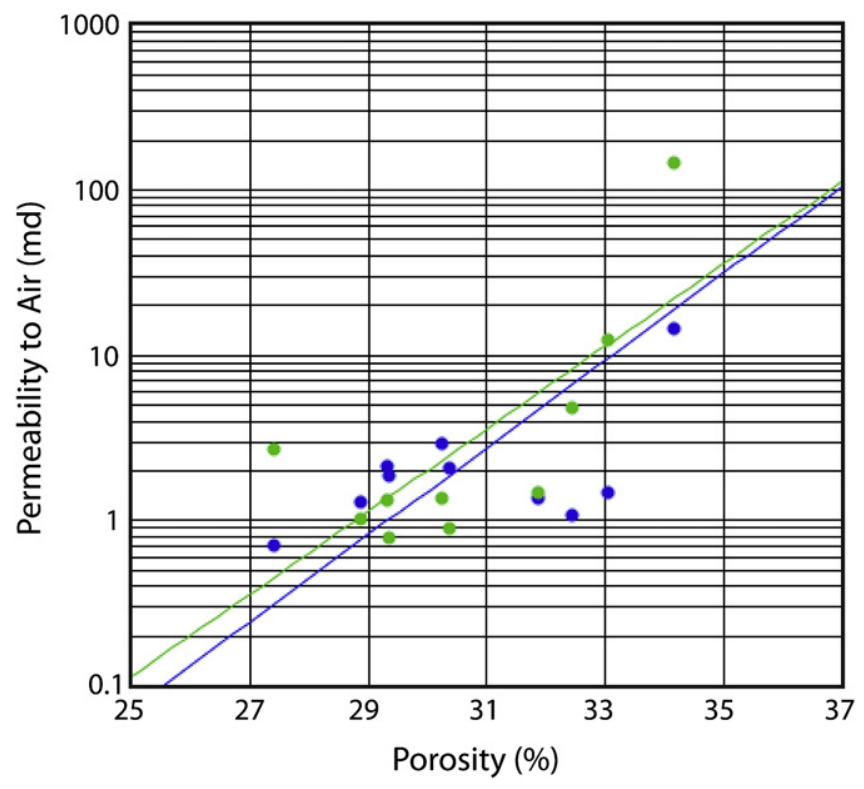

Fig. 15. Relationship between core-derived intrinsic (no gas hydrate present) permeability and porosity (from Winters et al. 2011). In the cleanest (shale-poor) and most porous units (porosity exceeding 35\%), intrinsic permeability (permeability with no gas hydrate present) exceed 1 darcy. However, modest decreases in porosity (to $\sim 30 \%$ or less) reduce permeability to 0.01 darcy or less. Green dots indicate permeability as measured from samples at net confining stress. Blue dots are permeability estimated from grain size analyses.

gas hydrates stability (BGHS), but instead tend to be rare near the BGHS, even where high-quality reservoirs are present, and more prevalent higher in the section (see Fig. 2). This seems to be true throughout the ANS (Collett et al., 2011a) and is clearly true at the Mount Elbert location. The lack of gas hydrate in the B unit and lower sands suggests that free gas did not pass through these reservoirs in great volumes while gas hydrate stability conditions were in effect. Second, as seen at Mount Elbert, gas hydrates are often largely restricted to the upper part of the sand units. In the case of the D unit, this could be a reflection of the occurrence of more favorable lithologies at the top of the formation; however, this is not the case with the $C$ unit, in which hydrate occurs in the upper most section (LS Va) even though this unit is of significantly lower reservoir quality (porosity and intrinsic permeability) than those within LS Vb. Third, gas hydrate tends to occur as discrete, concentrated deposits that show varying degrees of relation to trapping structures (see Inks et al., 2009). This is clearly seen at Mount Elbert, where both the C and D units appear to be trapped by at least one fault and are most highly concentrated at the crest of the closed folded structure. Finally, reservoir sands are often only partially filled, with relatively sharp basal contacts. Together, these features suggest the original buoyant separation of gas from water, with resultant preferential concentration in structural highs. The lack of gas hydrate in a reservoir such as the B unit at Mount Elbert is most likely due to a lack of trapping geometries in that unit during the period of gas charging. In the case of the B unit, the lack of trapping (prior to imposition of gas hydrate stability conditions) may be due to the lack of sufficient stratigraphic variation to develop the combination stratigraphic-structural traps that support the formation of gas deposits within the relatively gentle structures present within the overall monoclinal dip.

Therefore, we interpret that both the $C$ and $D$ accumulations at Mount Elbert formed as conventional gas accumulations some time before $\sim 1.8 \mathrm{Ma}$ (as per Collett, 1993, 2002; see also Dai et al., 2011). Due to buoyancy, these accumulations would have formed gas-water contacts in down dip positions that closely conform to structure assuming relatively consistent reservoir quality. This level would also equate to the structural elevation of any gaswater contact seen in updip wells. However, at Mount Elbert, there is a poor correspondence between these elevations. As with free
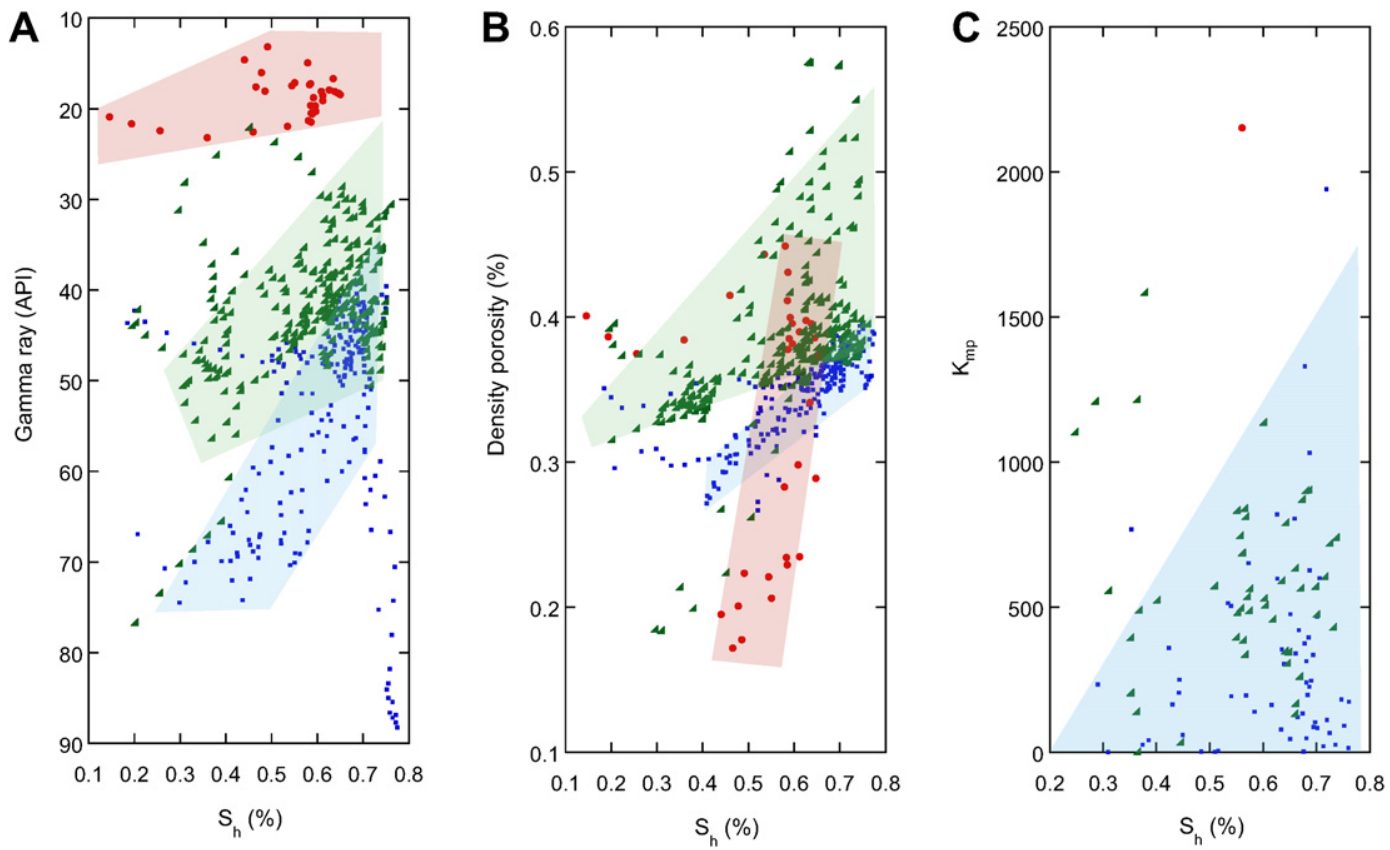

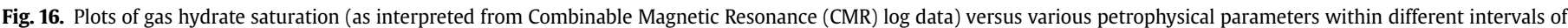

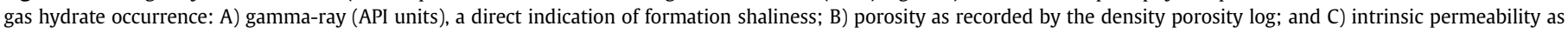
determined from mini-permeameter tests on the Mount Elbert core (see Winters et al., 2011). Shaded areas show overall trends within each unit. 
gas accumulations, these deviations can be generally attributed to lateral lithologic heterogeneities. Furthermore, due to a lack of case studies available, these relationships in the case of gas hydrate accumulations are less clear. Whether this poorly understood process of free-gas to gas-hydrate conversion would occur evenly on all flanks of the structure, and therefore maintain some conformance between the base of gas hydrate in the well and the down-dip extent of gas hydrate, is uncertain. A non-uniform availability of water around the structure could result in differential hydrate formation areally; however, if one assumes that no free gas currently exists within the structure, then it would appear that sufficient water was available to convert all pre-existing free gas to gas hydrate. The presence of stratigraphic heterogeneities within the reservoirs would further complicate this process. Continued delivery of methane to the accumulation subsequent to gas hydrate formation could additionally complicate these relationships.

Similarly, if the accumulations were previously-existing conventional gas traps as we believe, then it would be reasonable to expect the current gas hydrate to fill only a portion of the available closure or to occur at saturations less than what would be expected for a freegas accumulation (due to the more efficient concentration of methane in the gas hydrate form). With average saturations of roughly $65 \%$, it may be that the volumetric effect of conversion from gas hydrate to free gas is also accommodated by a general reduction in saturation in addition to the areal change in hydrocarbon occurrence (Behseresht et al., 2009). Nonetheless, in the D unit, the occurrence of gas hydrate to and beyond the apparent limits of the structural closure suggests a complex formation history. In addition, the size of the total available reservoir in the D unit, including stratigraphic variations, is not clear.

\subsection{Nature of gas hydrate occurrence on the flanks of the Mount Elbert structure}

The drilling of the Mount Elbert well confirms the pre-drill interpretation that the seismic amplitude anomalies associated with the Mount Elbert structure correspond to thick occurrences of gas hydrate at high saturations within sands in both the $C$ and $D$ units (Lee et al., 2011). However, these amplitude anomalies generally decline in magnitude away from the crest of the structure. Using the thin-bed analysis techniques presented in Lee et al. (2009), these amplitudes were interpreted to reflect simultaneous changes in reservoir thickness and $S_{h}$, with large areas assigned estimates of average $S_{h}$ ranging between 40 and $60 \%$. Alternative potential explanations for the observed amplitude decreases include 1) reductions in $S_{h}$ with relatively constant thickness and reservoir quality of the gas hydrate-bearing interval, 2) reductions in $S_{h}$ due to reductions in reservoir quality, or 3) relatively consistent $S_{h}$ with reduction in the thickness of the gas hydrate occurrence (Fig. 17).

The first option (Fig. 17a) - reduction in $S_{h}$ with generally consistent reservoir thickness and quality - would suggest a lack of sufficient gas supply to fully saturate the reservoir. In this scenario, the flanking regions of reduced $S_{h}$ may be a remnant of the process by which the pre-existing free gas accumulations were converted to gas hydrate. The gas hydrate occurrence would have presumably formed from the top down as hydrate stability conditions passed down through the section. Given the expected limited availability of water within the free-gas reservoir, it is not at all certain how this might happen, but if it did, the large fringing area of moderate $S_{h}$ now observed on the seismic data could develop due to some inability to move all the gas updip to feed the developing main gas hydrate accumulation, leaving gas behind for conversion to $S_{h}$ at reduced saturations as the base of gas hydrate stability descended toward the original gas-water contact within each unit. However, if this were the case, one would expect a similar zone of moderate $S_{h}$ in the sections vertically below the main hydrate accumulations at the Mount Elbert well, and no clear evidence for such exists within the log data. In fact, as described above, gas hydrate accumulations across the ANS seem to have relatively sharp, not transitional, basal contacts. Overall, the available data suggests that gas hydrate in sand reservoirs typically leaves only small free (or mobile) water saturations (which varies with reservoir quality both laterally and vertically) with limited documented cases of intermediate saturation (ex. Collett et al., 2009; Dallimore and Collett, 2005; Lee et al., 2011; Boswell et al., 2009). Nonetheless, there are few detailed case studies to reference, and the Mount Elbert core data do suggest large, low $S_{h}(<20 \%$; although not observed in log data, and not sufficient to create the seismic responses seen laterally) sections below the primary gas hydrate-bearing reservoirs, so this scenario clearly remains a possibility (Lee et al., 2009; Inks et al., 2009; Behseresht et al., 2009).

The second option (Fig. 17b) would suggest that the observed lateral reduction in amplitude is due to reduction in $S_{h}$ at relatively constant reservoir thickness due to progressive reduction in reservoir quality. In this case, the reservoir is still fully saturated to the extent the petrophysics allow, but that capacity is diminished due to reduction in intrinsic permeability. Given the high sensitivity of reservoir quality (in terms of permeability) to relatively modest changes in porosity observed in the Mount Elbert data set; a broad zone of precisely those intermediate conditions that seem to be required to produce moderate saturations seems unlikely. In addition, this option implies the coincidence that the best reservoir quality in both sands at the Mount Elbert well is located on, and roughly conformable to, the structural closures.
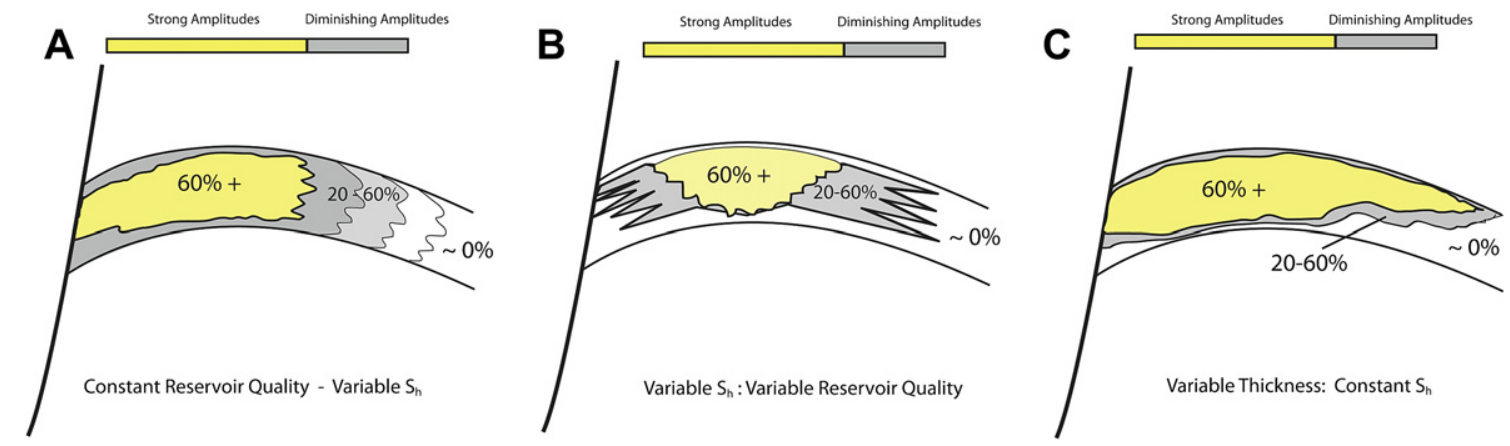

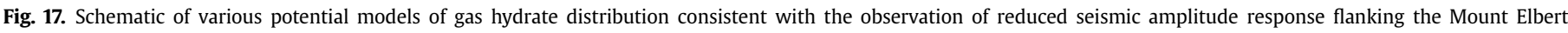
Structure: A) $S_{h}$ reduction within uniform reservoir; 2) $S_{h}$ reduction due to reduced reservoir quality; 3 ) thickness reduction at relatively consistent $S_{h}$. 
The third option (Fig. 17c) - reduced thickness of gas-hydratesaturated section within relatively uniform $S_{h}$ - would suggest a generally thinning accumulation away from the structural crest. This option is favorable as it conforms to the observations in the well, in which the boundaries of the gas hydrate accumulation are relatively sharp. This interpretation is also consistent with the proposed origin of the accumulation from pre-existing free gas traps, in which case total hydrocarbon thickness would tend to be maximum at the structural crest, and thin away due to the original buoyant separation of gas and water. Therefore, we suggest that the diminishing amplitudes on the flanks of the Mount Elbert structure are most likely due to reductions in amount of fill within the sands, with the fill that occurs being of relatively consistently high $S_{h}$.

Given this interpretation, isopach maps of the two accumulations can be prepared (Fig. 18). Incorporating the assumption of constant $S_{h}$ (we chose $65 \%$ for this analysis) into the thin-bed approach (which assumes simultaneously varying thickness and saturation) used in the original analyses of the Mount Elbert prospects (Lee et al., 2009) was not possible, so a modified approach was required. This modification involved using the net thickness of gas hydrate $\left(T_{n}\right)$ (given by $T_{n}=\phi S_{t} T_{t}$, where $S_{t}$ and $T_{t}$ are saturation and thickness) as determined from the thin bed analysis, and calculating the total reservoir thickness that would equate to this net thickness assuming constant $S_{h}$ of $65 \%$.

The complex stratigraphic/structural controls on gas hydrate occurrence at the Mount Elbert site are similar to those previously interpreted for permafrost-associated gas hydrate-bearing sands from the Mallik gas hydrate research program in Canada. At Mallik, three zones of gas hydrate occurrence were observed (Zones A, B, and C; see Dallimore and Collett, 2005). The upper zone (Zone A) at Mallik appears to be a case potentially similar to the Mount Elbert D unit sand, with $S_{h}$ and gas-hydrate/water contacts controlled primarily by changing reservoir quality (in particular by significant vertical changes in effective porosity; Katsube et al., 2005; Uchida et al., 2005). The middle gas hydrate bearing sand at Mallik (Zone B) directly overlies free-water bearing sands with no apparent lithologic control (similar to Mount Elbert C unit sand), and was interpreted to indicate insufficient charge (Dallimore and Collett, 2005). The lower zone (Zone C) at Mallik shows similar correlations between $S_{h}$ and reservoir quality, with the base of the accumulation likely being controlled by the base of gas hydrate stability with no free gas below, further indicating lack of gas charge (Dallimore and Collett, 2005).

\section{Summary}

Examination of log data acquired at the BPXA-DOE-USGS Mount Elbert well and reference to information from seismic data enables the following observations and conclusions regarding the nature, extent, and controls on gas hydrates within the Mount Elbert structure.

1. The Mount Elbert coring and logging program evaluated a series of Eocene sands of the Sagavanirktok Formation within the southeastern Milne Point Unit, Alaska North Slope. Within roughly $500 \mathrm{ft}$ of interbedded sands and shales, gas hydrates were found to be limited to sand reservoirs within the C and D units of Collett (1993).

2. Gas hydrate appears to fully saturate the upper portions of both sands with the loss of sand reservoir controlling the upper extent of the deposits. Both units are capped by thick $(>10 \mathrm{~m})$ shale-dominated sections of reduced permeability that have acted as seals.

3. Where gas hydrate occurs, $S_{h}$ is generally high (60\% or greater) and varies within the accumulations in rough accordance with changes in reservoir quality as represented by gamma-ray inferred shale volume and density porosity.

4. The basal contact of gas hydrate in the D unit is relatively sharp, despite overall gradual change in reservoir quality, and is coincident with subtle but significant lithologic and petrophysical changes. However, the possibility that the contact reflects a limitation in charge or in the sealing capacity of the upper seal, with the reservoir in contact with a thin basal freewater zone, cannot be ruled out.

5. Complex stratigraphic variations within the $C$ unit produce two gas hydrate-water contacts. Neither contact can be related to significant stratigraphic changes within the individual unit. Therefore the $C$ unit appears to be a composite of two partiallyfilled reservoirs, each with gas hydrate bearing sands in direct contact with potentially extensive high-permeability, waterbearing reservoirs.

6. The comparison of the areal extent of the seismic anomaly, the mapped structural configuration of the units, and information from the Mount Elbert well, suggest that the C and D accumulations represent combination structural-stratigraphic traps. Primary structural controls are a sealing fault that forms
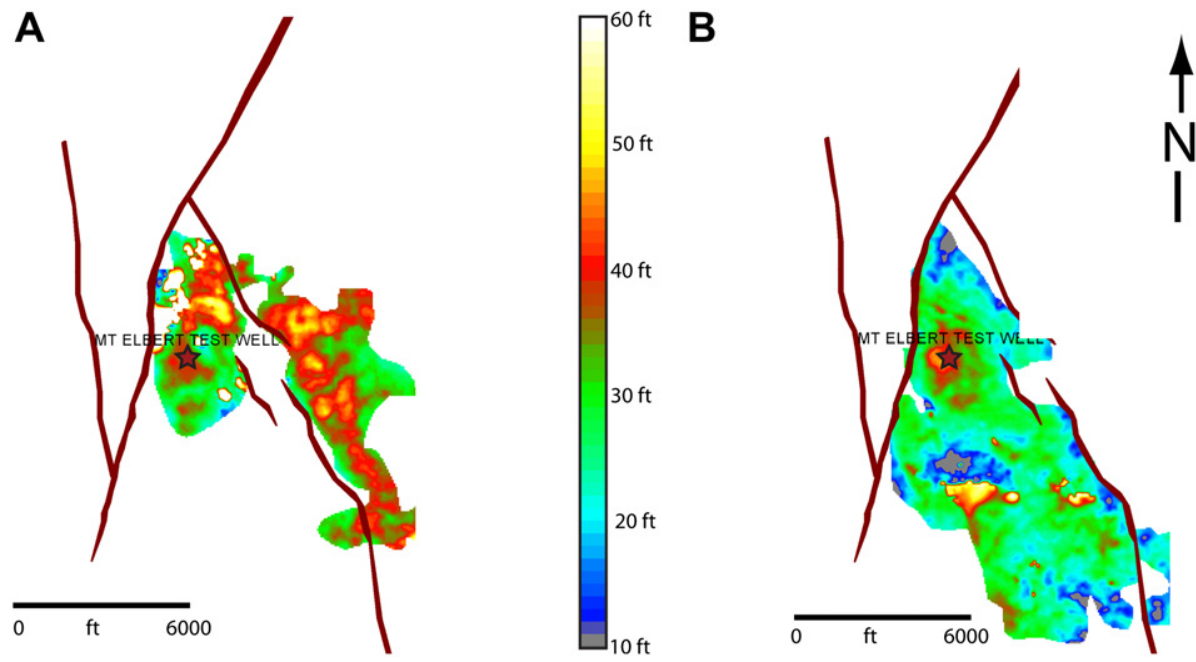

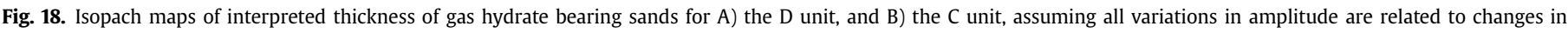
thickness at constant average reservoir saturation. 
the western boundary of both accumulations, and a subtle fourway closed anticlinal structure.

7. Seismic amplitude data indicates that the most significant accumulations of gas hydrate in both sands (as determined by strongest seismic amplitudes) occur along the crest of the anticlinal closure. The proximity of this closure to the primary fault suggests that it was an initial locus of trapping of hydrocarbons.

8. Seismic amplitudes decrease away from the fold crest, and extend asymmetrically around this closure to elevations with no clear relationship to the base of gas hydrate as observed at the well. We attribute this to gradual reductions in thickness of gas-hydrate-bearing sediments, although other explanations are considered.

9. For the D unit, the occurrence of gas hydrate outside the interpreted closure indicates that the lateral limits on the accumulation are largely controlled by lateral stratigraphic variations. For the $C$ unit, the primary lateral control on gas hydrate occurrence is the pinch-out of the upper C unit (LS Va). The small secondary accumulation within the lower C unit (LS $\mathrm{Vb}$ ) may be entirely structurally controlled but small scale lithologic changes are present and may have influenced this occurrence.

10. The observations at Mount Elbert are in keeping with prior observations that the $\mathrm{C}$ and $\mathrm{D}$ gas hydrate accumulations formed originally as free-gas pools within combination structural-stratigraphic traps. Overall, it is postulated that free gas migrating up the western bounding fault entered and was trapped within the $\mathrm{C}$ - and D-units within the fold closure. Lack of gas in the lower B sand is likely due to lack of trapping geometries in this unit. These accumulations were later converted to gas hydrate through physical processes that are not currently well understood.

11. We interpret that gas hydrate most likely remains at relatively high $S_{h}$ throughout its extent, with the previously mapped variations in seismic amplitude (Inks et al., 2009) driven primarily by lateral changes (primarily reductions) in reservoir thickness away from the structural crest.

\section{Acknowledgements}

The authors wish to thank BPXA for access to data and for leadership in advancing gas hydrate research on the Alaska North Slope. We thank the BPXA engineers who planned the Mount Elbert drilling program and crew of the Doyon-14 for their safe and efficient execution of the drilling. We also thank those that contributed to the selection of the Mount Elbert site (Tanya Inks, Dave Taylor, Mariana Zyrianova), members of the Mount Elbert Science Party (Micaela Weeks, Bob Hunter, Steve Hancock, Marta Torres, Rick Colwell, Bill Waite, Tom Lorenson, and Eilis Rosenbaum) and all the scientists who have participated in the post-field analysis of the Mount Elbert datasets whose work appears in other contributions to this special volume.

\section{References}

Anderson, B., Hancock, S., Wilson, S., Collett, T., Boswell, R., Hunter, R., 2011. Formation pressure testing at the Mount Elbert Gas Hydrate Stratigraphic Test Well, Alaska North Slope: Operational summary, history matching, and interpretations. Marine and Petroleum Geology 28 (2), 478-492.

Bidinger, C., Dillon, J., 1995. Milne Point Schrader Bluff; Finding the Keys to Two Billion Barrels. SPE 30289. In: Int'l Heavy Oil Symposium. Calgary, Alb.

Bird, K., 1998. Geographic and geologic setting. Chapter GG. In: ANWR Assessment Team (Ed.), The Oil and Gas Resource Potential of the Arctic National Wildlife Refuge 1002 Area, Alaska. http://pubs.usgs.gov/of/1998/ofr-98-0034/GG.pdf, U.S. Geological Survey Open-File Report 98-34. Version 1.0, p. GG1-GG51, CD-ROM.

Behseresht, J., Peng, Y., Bryant, S., Winters, W., 2009. Sedimentological control on arctic gas-hydrate-bearing deposits. In: Proceedings American Geolophysical Union, Annual Meeting, December 2009.
Boswell, R., Shelander, D., Lee, M., Latham, T., Collett, T., Guerin, G., Moridis, G., Reagan, M., Goldberg, D., 2009. Occurrence of gas hydrate in oligocene frio sand; alaminos canyon block 818, northern Gulf of Mexico. Marine and Petroleum Geology 26, 1499-1512.

Carman, G., Hardwick, P., 1983. Geology and regional setting of Kuparuk oil field, Alaska. American Association of Petroleum Geologists Bulletin 67, 1014-1031.

Collett, T., Kvenvolden, K., Magoon, L., 1990. Characterization of hydrocarbon gas within the stratigraphic interval of gas-hydrate stability on the North Slope of Alaska. Applied Geochemistry 5, 279-287.

Collett, T., 1993. Natural gas hydrates of the Prudhoe Bay and Kuparuk River area, north slope, Alaska. American Association of Petroleum Geologists Bulletin 77 (5), 793-812.

Collett, T., 2002. Energy resource potential of natural gas hydrates. American Association of Petroleum Geologists Bulletin 86 (11), 1971-1992.

Collett, T., Lee, M., Agena, W., Miller, J., Lewis, K., Zyrianova, M., Boswell, R., Inks, T., 2011a. Permafrost-associated natural gas hydrate occurrences on the Alaska North Slope. Marine and Petroleum Geology 28 (2), 279-294.

Collett, T., Lewis, R., Winters, W., Lee, M., Rose, K., Boswell, R., 2011b. Downhole well $\log$ and core montages from the Mount Elbert gas hydrate stratigraphic test well, Alaska North Slope. Marine and Petroleum Geology 28 (2), 561-577.

Collett, T., Johnson, A., Knapp, C., Boswell, R., 2009. Natural gas hydrates a review. In: Collett, T., Johnson, A., Knapp, C., Boswell, R. (Eds.), Natural Gas Hydrates - Energy Resource Potential and Associated Hazards. AAPG Memoir, vol. 89.

Collett, T., Riedel, M., Cochran, J., Boswell, R., Presley, J., Kumar, P., Sathe, A., Sethi, A., Lall, M., Sibal., V., the Indian National Gas Hydrate Program Expedition 01 Scientific party, 2008a. Indian National Gas Hydrate Program Expedition 01 initial reports: prepared by the U.S. Geological Survey and the Directorate General Hydrocarbons, Ministry of Petroleum and Natural Gas (India), DVD.

Dai, S., Lee, C., Santamarina, C., 2011. Formation history and physical properties of sediments from the Mount Elbert Gas Hydrate Stratigraphic Test Well, Alaska North Slope. Marine and Petroleum Geology 28 (2), 427-438.

Dallimore, S., Collett, T. (Eds.), 2005. Scientific Results From the Mallik 2002 Gas Hydrate Production Research Well Program, Mackenzie Delta, Northwest Territories, Canada. Geological Society of Canada Bulletin, vol. 585.

Fujii, T., Saeki, T., Kobayashi, T., Inamori, T., Hayashi, M., Takano, O., Takayama, T., Kawasaki, T., Nagakubo, S., Nakamizu, M., Yokoi, K. 2008. Resource Assessment of Methane Hydrate in the Eastern Nankai Trough, Japan, Offshore Technology Conference, OTC 19310.

Hadley, C., Peters, D., Vaughan, A., Bean, D. 2008. Gumusut-Kakap project: geohazard characterization and impact on field development plans. In: International Petroleum Technology Conference IPTC-12554. p. 15.

Holland, M., Schultheiss, P., Roberts, J., Druce, M. 2008. Observed gas hydrate morphologies in marine sediments. In: Proceedings, 6th International Conference on Gas Hydrates (ICGH 2008).

Hunter, R., Collett, T., Boswell, R., Anderson, B., Digert, S., Pospisil, G., Baker, R., Weeks, M., 2011. Mount Elbert Gas Hydrate Stratigraphic Test Well, Alaska North Slope: Overview of scientific and technical program. Marine and Petroleum Geology 28 (2), 295-310.

Hyndman, R., Davis, E., 1992. A mechanism for the formation of methane hydrate and sea floor bottom simulating reflections by vertical fluid explusion. Journal of Geophysical Research 97, 7025-7041.

Inks, T., Lee, M., Agena, W., Taylor, D., Collett, T., Hunter, T., Zyrianova, M., 2009. Seismic prospecting for gas hydrate and associated free gas prospects in the Milne Point area of northern Alaska. In: Collett, T., Johnson, A., Knapp, C., Boswell, R. (Eds.), Natural Gas Hydrates - Energy Resource Potential and Associated Hazards. AAPG Memoir, vol. 89.

Katsube, T., Dallimore, S., Jonasson, I., Connell-Madore, S., Medioli, B., Uchida, T. Wright, J., Scromeda, N., 2005. Petrophysical characteristics of gas-hydratebearing and gas-hydrate-free formations in the JAPEX/JNOC/GSC et al. Mallik 5L-38 gas hydrate production research well. In: Dallimore, S., Collett, T. (Eds.) Scientific Results Form the Mallik 2002 Gas Hydrate Production Research Well Program, Mackenzie Delta, Northwest Territories, Canada. Geological Society of Canada Bulletin, vol. 585.

Lee, M., Agena, W., Collett, T., Inks, T., 2011. Pre- and post-drill comparison of the Mount Elbert gas hydrate prospect at the Milne Point area, Alaska North Slope. Marine and Petroleum Geology 28 (2), 578-588.

Lee, M., Collett, T., 2011. In-situ gas hydrate saturations estimated from various well logs at the Mount Elbert well, Alaska North Slope. Marine and Petroleum Geology 28 (2), 439-449.

Lee, M., Collett, T., Inks, T., 2009. Seismic attribute analysis for gas-hydrate and freegas prospects on the North Slope of Alaska. In: Collett, T., Johnson, A., Knapp, C., Boswell, R. (Eds.), Natural Gas Hydrates - Energy Resource Potential and Associated Hazards. AAPG Memoir, vol. 89.

Lorenson, T., Collett, T., Hunter, R., 2011. Gas geochemistry of the Mount Elbert gas hydrate test well, Milne Pt. Alaska. Implications for gas hydrate exploration Arctic. Marine and Petroleum Geology 28 (2), 343-360.

Masterson, D., Dzou, L., Holba, A., Fincannon, A., Ellis, L., 2001. Evidence for biodegradation and evaporative fractionation in west Sak, Kuparuk, and Prudhoe Bay field areas, north slope, Alaska. Organic Geochemistry 32 (3), 411-441.

Molenaar, C., Bird, K., Kirk, A., 1987. Cretaceous and tertiary stratigraphy of northeastern Alaska. In: Tailleur, I., Weimer, P. (Eds.), Alaskan North Slope geology: Society of Economic Paleontologists and Mineralogists, Pacific Section, Book 50, vol. 2, pp. 513-528. 
R. Boswell et al. / Marine and Petroleum Geology 28 (2011) 589-607

607

Milkov, A.V., Sassen, R., 2002. Economic geology of offshore gas hydrate accumulotions and provinces. Marine and Petroleum Geology 19, 1-11.

Park, K., 2008. Gas hydrate exploration activities in Korea. In: Proceedings, th International Conference on Gas Hydrates (ICGH 2008), p. 10.

Pauli, C., Matsumoto, R., Wallace, P. (Eds.), 1996. Initial Reports - Gas Hydrate Sampling on the Blake Ridge and Carolina Rise. Proceedings of the Ocean Drilling Program, vol. 164. Ocean Drilling Program, Texas A\&M University, College Station, TX, p. 623.

Riedel, M., Collect, T., Malone, M., Expedition 311 scientists, 2006. In: Proceedings of the Integrated Ocean Drilling Program, vol. 311. Ocean Drilling Program, Washington, DC. doi:10.2204/iodp.proc.311.2006.

Rose, K., Boswell, R., Collets, T., 2011. Mount Elbert Gas Hydrate Stratigraphic Test Well, Alaska North Slope: Coring operations, core sedimentology, and lithotratigraphy. Marine and Petroleum Geology 28 (2), 311-331.

Sloan, D., Kob, C., 2008. Clathrate Hydrates of Natural Gases, third ed. CRC Press, Taylor and Francis Group, Publishers, New York, 721 pp.

Sun, Y., Goldberg, D., Collett, T., Hunter, R., 2011. High-resolution well-log derived dielectric properties of gas-hydrate-bearing sediments. Marine and Petroleum Geology 28 (2), 450-459.

Torres, M., Collets, T., Rose, K., Sample, J., Agenda, W., Rosenbaum, E., 2011. Pore fluid geochemistry from the Mount Elbert gas hydrate stratigraphic test well, Alaska North Slope. Marine and Petroleum Geology 28 (2), 332-342.

Torres, M., Trehu, A., Cespedes, N., Kastner, M., Wortmann, U., Kim, J., Long, P., Malinverno, A., Pohlman, J., Riedel, M., Colet, T., 2008. Methane hydrate formation in turbidity sediments of northern Cascadia, IODP Expedition 311. Earth and Planetary Science Letters 271, 170-180.

Uchida, T., Tsuji, T., Takahashi, T., Okui, T., Minagawa, H., 2005. Petrophysical properties and sedimentology of gas-hydrate-bearing sediments in the JAPEX/
JNOC/GSC et al. Mallik 5L-38 gas hydrate production research well. In: Dallimore, S., Colet, T. (Eds.), Scientific Results Form the Mallik 2002 Gas Hydrate Production Research Well Program, Mackenzie Delta, Northwest Territories, Canada. Geological Society of Canada Bulletin, vol. 585.

Uchida, T., Waseda, A., Namikawa, T., Boswell, R., 2009. Methane accumulation and high concentration of gas hydrate in marine and terrestrial sandy sediment. In: Collett, T., Johnson, A., Knapp, C., Boswell, R. (Eds.), Natural Gas Hydrates Energy Resource Potential and Associated Hazards. AAPG Memoir, vol. 89.

Vain, Z., Collets, T., 1992. Molecular and Isotopic Analyses of the Hydrocarbon Gases Within Gas Hydrate-bearing Rock Units of the Prudhoe Bay-Kuparuk River Area in Northern Alaska, vol. 92-299. U.S. Geological Survey Open-File Report, $90 \mathrm{p}$.

Werner, M., 1987. Tertiary and upper Cretaceous heavy oil sands, Kuparuk River area, Alaskan North Slope. In: Tailleur, I.L., Weimer, Paul (Eds.), Alaskan North Slope Geology: Bakersfield, California, Pacific Section, Society of Economic Paleontologists and Mineralogists and the Alaska Geological Society, Book 50, vol. 1, pp. 109-118.

Wilson, S., Hunter, R., Collett, T., Hancock, S., Boswell, R., Anderson, B., 2011. Alaska North Slope regional gas hydrate production modeling forecasts. Marine and Petroleum Geology 28 (2), 460-477.

Winters, W., Walker, M., Hunter, R., Collets, T., Boswell, R., Rose, K., Torres, M., Patil, S., Dandekar, A., 2011. Physical properties of sediment from the Mount Elbert gas hydrate stratigraphic test well, Alaska North Slope. Marine and Petroleum Geology 28 (2), 361-380.

Yang, S., Chang, H., Wu, N., Su, X., Schultheiss, P., Holland, M., Zhang, G., kiang, J., Lu, J., Rose, K., 2008. High concentration of hydrate in dessiminated forms obtained in Shenhu area, North Slope of South China Sea. In: Proceedings, 6th Internetonal Conference on Gas Hydrates (ICGH 2008), p. 10. 